
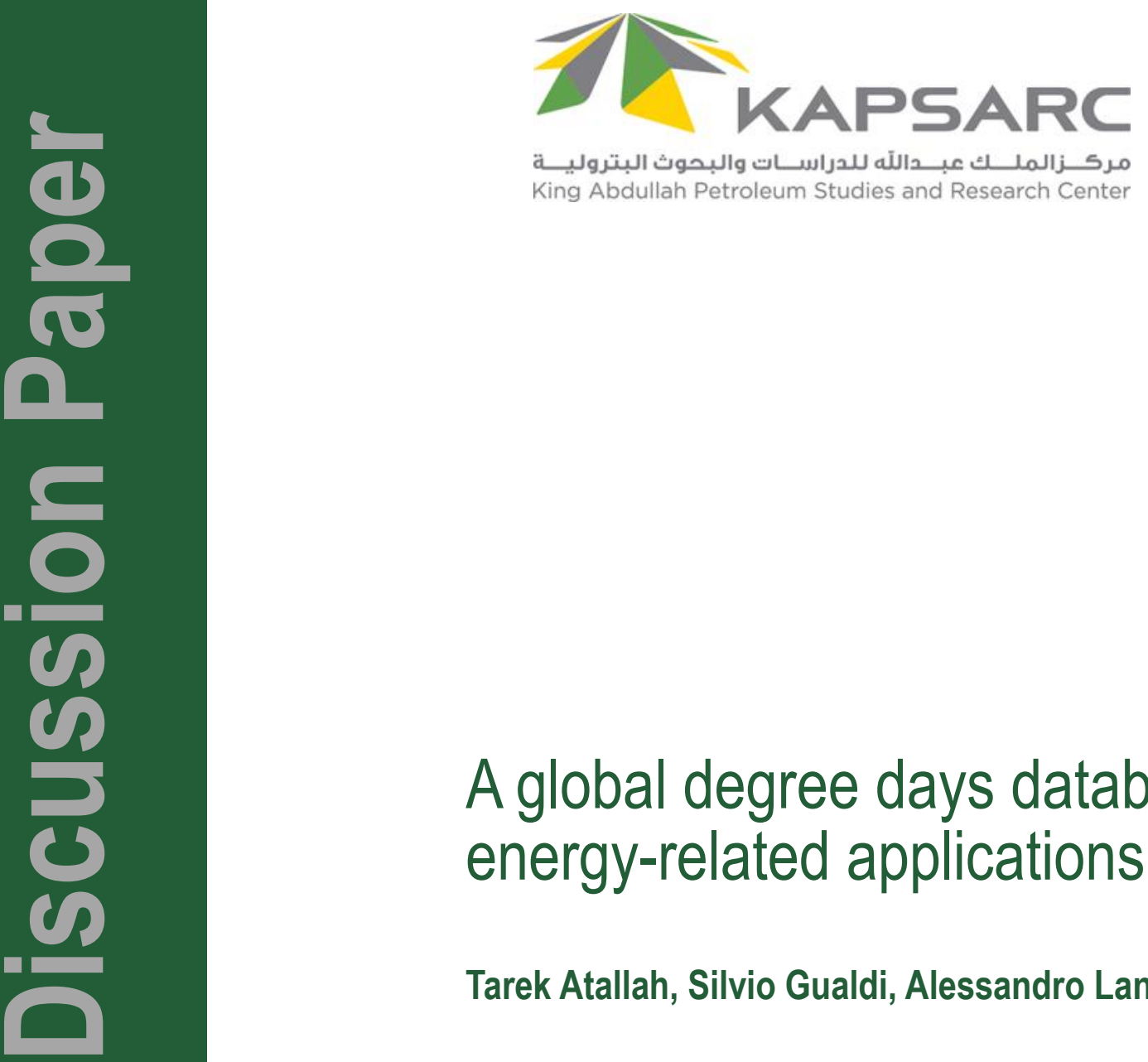

\title{
A global degree days database for energy-related applications
}

Tarek Atallah, Silvio Gualdi, Alessandro Lanza 


\section{About KAPSARC}

The King Abdullah Petroleum Studies and Research Center (KAPSARC) is an independent, non-profit research institution dedicated to researching energy economics, policy, technology, and the environment across all types of energy. KAPSARC's mandate is to advance the understanding of energy challenges and opportunities facing the world today and tomorrow, through unbiased, independent, and high-caliber research for the benefit of society. KAPSARC is located in Riyadh, Saudi Arabia.

\section{Legal notice}

(C) Copyright 2015 King Abdullah Petroleum Studies and Research Center (KAPSARC). No portion of this document may be reproduced or utilized without the proper attribution to KAPSARC. 


\section{Summary for policymakers}

Weather can have a profound effect on energy consumption, especially extremes of hot and cold temperatures. These variations in particular drive residential and commercial energy demand because space heating and cooling is such an important component. Traditional approaches are customized to the specific geography of interest. Energy regulators use a measure of divergence from normal temperatures to estimate peaks in demand when planning future capacity, or to strip out short-term weather effects to identify underlying growth trends. Energy traders marry weather forecasts to demand data to identify potential price peaks and troughs. What unites these analyses is that they tend to be either local or short term in nature; or both. However, the customization of methodology to a particular geography renders comparisons of the effects of weather between countries invalid.

Targets for improving energy productivity and benchmarking of performance towards meeting such targets between countries requires a consistent global database, both spatially and temporally. To date, no such database has been available to policymakers. KAPSARC has worked with the Euro -Mediterranean Center for Climate Change (CMCC) to create a database covering 147 countries over a period of several decades, based on consistent methodologies such that the impacts of local climate on energy consumption can be analyzed.

Differences in the energy productivity of countries are comprised of several factors. These include the industrial structure of the economy, efficiency of equipment and processes, availability of water, and differences in weather-among other factors. Differentiating between the factors that are controllable (including economic structure and efficiency) and uncontrollable (including weather and access to water), allows policy to be focused in the areas where it can achieve the most beneficial impact. The CMCC-KAPSARC Weather Normalization Database is one of the tools now available to policymakers to separate the signal from the noise in guiding policies aimed at improving the energy productivity of their economies.

\section{Introduction}

The cooling and heating degree days methodology is regarded as a reliable tool for appropriately accounting for the effect of weather on energy demand. Degree days methodologies are commonly used to calculate seasonally adjusted energy consumption in a variety of discrete geographies. These include, among others, Dombayci (2009) for Turkey, Arguez et al (2013) for the United States, Badescu et (1999) for Romania, You (2013) for China, Matzarakis (2004) for Greece, Al-Hadrami (2013) for Saudi Arabia, and Eurostat (2011) for selected European countries.

The various databases available in the literature are generated under a variety of definitions and methodologies and based on a range of reference temperatures. These are useful for planning energy systems and predicting seasonal load demands for evening out weather related variations in energy demand, and are also equally used by traders and economist for analyzing competitive market-derived prices. Furthermore, quantifying the relationship between climatic conditions and energy consumption can raise awareness on the effect of climate change on future heating and cooling equipment investments (De Cian et al, 2013; Bigano et al, 2006; Christenson et al, 2006).

From a policymaking perspective, accounting for weather effect on energy demand is no longer restricted to domestic nationally-focused analysis. 
There is also an emerging international context. Decision makers have increasingly noted the need for benchmarking the performance of their economies and the effect of their policies against other countries. However, the fragmented nature of degree days datasets, their lack of comprehensive coverage, and the variations in definition of weather adjustments make such comparison between countries difficult or even invalid. Furthermore, the majority of the calculated datasets only include the effects of temperature. They do not always address the potential effects of humidity and solar radiation, both of which may drive demand for air conditioning and heating.

There are some studies in the literature that take a global perspective using a country-by-country data. The World Resource Institute (Baumert K., Selman M., (2003) for example, used ground-based station temperature data to create a 30-year average of cooling (CDD) and heating degree-days (HDD) for around 90 countries. However, the dataset has not been updated and, for many countries, excludes large proportions of population and land area. Wheeler (2012) developed a global population weighed CDD and HDD database using temperature records from 1980 to 2011, gathered from satellite reanalysis data. The dataset, however, is limited by the fixed reference temperature, the spatial and temporal aggregation associated with its analysis and the absence of other relevant climatic factors including humidity. Eurostat (2011) provides a monthly Heating Degree Day index for European Union countries for the period 1980 to 2009, while Benestad (2008) generated CDD and HDD estimations and forecasts for 63 Europeans locations from 1900 to 2100 . Although these datasets include various countries, they are characterized by different spatial and temporal aggregation levels, and use calculation methodologies that hinder reliable comparisons between countries.
In partnership with the Euro-Mediterranean Center for Climate Change (CMCC), KAPSARC has created, a comprehensive dataset in both geography and time that overcomes these limitations, allowing policymakers to make unbiased and comparable evaluations among countries. Its intention is to enable policymakers to account for differences in energy consumption that simply result from diverging climatic conditions between their own country and a comparator. This allows comparison of normalized data to determine whether residual differences are driven by other factors - including structure of economy, efficiency or consumer behavior. Moreover, this dataset is freely available to the public.

\section{Building of the database}

The CMCC-KAPSARC database provides data on population-weighted degree-days for 147 countries for the period ranging from 1948 to 2013. An important aspect of its development was to improve on existing degree days methodology, namely limited geographical availability, temporal and spatial aggregation, the lack of accounting for various climatic factors, and the restrictive use of a singular reference temperature.

The dataset was created through a combination of gridded atmospheric satellite datasets developed by the National Oceanographic Atmospheric Agency (NOAA). Degree days have been computed using datasets obtained from NOAA's National Centers for Environmental Prediction (NCEP/NCAR reanalysis first started by Kalnay et al, 1996). The data series employed were actual values and reanalysis of geo-located climate parameters: air temperature at two meters altitude, relative humidity, solar radiation available at a four times intra-day frequency ranging from 1948 through 2013. 
These parameters were used to calculate global thermal comfort indices within grids determined by latitude and longitude at a spatial resolution of $1.8^{\circ}$ $x 1.8^{\circ}$. The value of a decimal degree $\left(1^{\circ}\right)$ of longitude fluctuates between $40 \mathrm{~km}$ and $112 \mathrm{~km}$, depending on the location distance from the equator. One degree of latitude remains $112 \mathrm{~km}$ regardless of location. Each of the resulting indices was represented on a Gaussian grid of 192 longitudes and 94 latitudes, for 96,428 time values at six hour intervals.

Computed indices were population-weighted using Columbia University's Gridded Population of the World dataset (GPW v.3) from 1990 to 2013, and extrapolations from UNEP/GRID-Sioux Falls regional datasets for the years ranging from 1948 to 1990. The population-weighting procedure is important in order to avoid over-estimating energy consumption in areas with extreme weather conditions but without resident population. The resulting indices were subsequently downscaled to an enhanced resolution of $1.6^{\circ} \times 1.6^{\circ}$ using statistical regressions, and shaped into national boundaries using GIS geocoding. All the local values of the sub-indices were summed to create annual national indices. Grids overlapping multiple boundaries were split proportionally to the respective surface of each country within the grid. Cooling and heating degree days for each index were calculated by taking the absolute difference between the sub-daily index value and thermal comfort index calculated using the reference climatic factors. These were set to be $60^{\circ} \mathrm{F}$, $65^{\circ} \mathrm{F}$ or $70^{\circ} \mathrm{F}$ equivalent to $15.6^{\circ} \mathrm{C}, 18.3^{\circ} \mathrm{C}$ or $21.1^{\circ}$ $\mathrm{C}$, respectively.

Different policymakers may have different preferences to which index to use depending on whether their predominant loads are heating or cooling, and whether the demand is concentrated on the coast or inland. The CMCC-KAPSARC dataset can be used in a variety of flexible ways. It includes degree days based on pure temperature readings, as well as others derived from thermal comfort indices that are calculated based on additional climatic parameters. The inclusion of these parameters helps convey the actual "feels-like" temperature that is sensed by human bodies and that triggers demand for air conditioning.

The dataset includes degree days based on five thermal indicators which are explained in detail in Appendix 1. These are:

- Temperature (T2m_C measured in $\left.{ }^{\circ} \mathrm{C}\right)$

- Temperature (T2m_F measured in $\left.{ }^{\circ} \mathrm{F}\right)$

- Heat index (HI, measured in $\left.{ }^{\circ} \mathrm{F}\right)$

- Humidex (HUM, measured in ${ }^{\circ} \mathrm{C}$ )

- Environmental Stress Index (ESI, measured in $\left.{ }^{\circ} \mathrm{C}\right)$

The first two indices are both temperature-based but with different thermal units, Celsius and Fahrenheit. Celsius degree days cannot be derived from Fahrenheit days (and vice versa), as the relationship between the two is not linear. Furthermore, having the temperature-based indices in the two units facilitates the ensuing comparison effort with the existing data in the literature, and the degree days for thermal comfort indices.

The Heat Index was developed by the US National Oceanographic and Atmospheric Administration (NOAA) in 1978 and adopted by the US National Weather Service a year later. It aims at combining the effects of air temperature and relative humidity into a single parameter that provides a measure of the perceived temperature in degrees Fahrenheit. It was empirically derived by Rothfusz (1990) for specific conditions of temperature and relative humidity, and later expanded by NOAA's Climate Prediction Center to be defined at all values. Higher values of Heat Index correspond to hotter perceived environmental conditions. 
The Humidex is an index developed and frequently used by the Meteorological Service of Canada, first defined by Richardson et al (1979). It is defined in Celsius and, similar to the Heat Index, aims at deriving a "feels-like" temperature-based on the consideration of temperature and relative humidity. As with the Heat Index, higher values of the Humidex reflect hotter perceived conditions.

The last thermal comfort index that we enumerate is the Environmental Stress Index (ESI) which adds the effect of solar radiation on temperature and relative humidity. It was defined by Moran et al (2001) as an improvement and proxy for the wetbulb temperature based index. There are other thermal comfort indices, such as the Thom's Index, the Standard Effective Temperature, the Modified Discomfort Index and Universal Thermal Climate Index (Epstein et al, 2006). These indices have not been included in our current database, either because they offer an approach too simplistic or they require parameters for their calculations that are not commonly available on a global scale (such as the mean radiant temperature, clothing levels or metabolic rates).
Choosing the reference for the various thermal comfort indices is not a straightforward exercise as additional variables are involved in the process. We use a combination of reference variables that will result in a thermal comfort index equal to $60^{\circ} \mathrm{F}, 65^{\circ} \mathrm{F}$ or $70^{\circ} \mathrm{F}$ or the equivalent in Celsius degrees. These arrangements of variables are specific to each index depending on the additional climatic variables that are included. For simplicity, the values of relative humidity and daily average solar radiation were kept constant at $40 \%$ and $300 \mathrm{~W} / \mathrm{m} 2$ respectively, while finding the temperature value that will yield to the reference value of the index. The daily average solar radiation was calculated based on the average solar radiation arriving at the top of the Earth's atmosphere which is roughly $1.3 \mathrm{~kW} / \mathrm{m} 2$ (Kopp and Lean, 2011), dissipated through the atmosphere and the clouds. The resulting value of $300 \mathrm{~W} / \mathrm{m} 2$ is assumed as the daily solar radiation accounting for the effect of reducing radiation during dark hours. The values of the ideal relative humidity was set as the ideal value for the human body comfort, obtained from recommendations put forth by the Environment Protection Agency for household thermal comfort. Table 1 below shows the corresponding modified base temperature for each index.

\begin{tabular}{|c|c|c|}
\hline Index Name & Equivalent Index Value & Corresponding Base Temperature \\
\hline & $15.6^{\circ} \mathrm{C}$ & $13.98^{\circ} \mathrm{C}$ \\
\hline Humidex & $18.3^{\circ} \mathrm{C}$ & $17.40^{\circ} \mathrm{C}$ \\
& $21.1^{\circ} \mathrm{C}$ & $21.09^{\circ} \mathrm{C}$ \\
\hline Environmental Stress Index & $15.6^{\circ} \mathrm{C}$ & $12.60^{\circ} \mathrm{C}$ \\
& $18.3^{\circ} \mathrm{C}$ & $14.90^{\circ} \mathrm{C}$ \\
Heat Index & $21.1^{\circ} \mathrm{C}$ & $17.20^{\circ} \mathrm{C}$ \\
& $60.0^{\circ} \mathrm{F}$ & $57.56^{\circ} \mathrm{F}$ \\
\hline Table 1: Corresponding base temperatures for selected indices at $\mathrm{RH}=40 \%$ and SR= $300 \mathrm{Q} \mathrm{W} / \mathrm{m} 2$ & $63.08^{\circ} \mathrm{F}$ \\
Source: KAPSARC & $65.0^{\circ} \mathrm{F}$ & $68.58^{\circ} \mathrm{F}$ \\
\hline
\end{tabular}


Finally, although the NCEP re-analysis cover the 1948-2013 period, the earlier part of the dataset is mostly based on the model dynamics with only little contribution from actual observations. The contribution of the observational data to the reanalysis products, in the second half of the covered time-period, especially for emerging economies, is more reliable in our view. For the purpose of the ensuing analysis, this paper will focus on the last five decades of the time series (1964-2013), keeping only the most reliable parts of the re-analysis products. Values were calculated for 147 countries, while nations with an area smaller than $1000 \mathrm{~km}^{2}$ were disregarded due to data granularity issues. These include island nations like Nauru or Barbados, or city-states such as Monaco or the Vatican.

\section{A brief description of the database}

Table 2 below reflects country rankings by the number of HDD and CDD derived for various thermal comfort indices at a nominal reference temperature of $18.3^{\circ} \mathrm{C}$ or $65^{\circ} \mathrm{F}$. For the HDD, Kyrgyzstan and Mongolia stand out as the coldest countries across all indices. Norway, Finland, Russia, and Kazakhstan are among the next coldest. CDD provides more variation among the countries. The highest CDD countries change depending on the chosen index and reference temperature. Mauritania, UAE and Niger are leading the ranks for the temperature based indices while in general East Timor, Cuba and The Philippines top the remaining indices. More detail is available in Appendix 2, which shows descriptive statistics for the years 1964-2013.

\begin{tabular}{|c|c|c|c|c|c|c|c|}
\hline \multicolumn{2}{|c|}{ Temperature-based } & \multicolumn{2}{|c|}{ Heat Index } & \multicolumn{2}{|c|}{ Humidex } & \multicolumn{2}{|c|}{ ESI } \\
\hline HDD & CDD & HDD & CDD & HDD & CDD & HDD & CDD \\
\hline $\begin{array}{l}\text { Kyrgyz Rep. } \\
(7715)\end{array}$ & $\begin{array}{c}\text { Mauritania } \\
\text { (3642) }\end{array}$ & $\begin{array}{c}\text { Kyrgyz Rep. } \\
\text { (13442) }\end{array}$ & $\begin{array}{c}\text { East Timor } \\
(8017)\end{array}$ & $\begin{array}{c}\text { Kyrgyz Rep. } \\
\text { (8544) }\end{array}$ & $\begin{array}{l}\text { Philippines } \\
\text { (7242) }\end{array}$ & $\begin{array}{l}\text { Kyrgyz Rep. } \\
\text { (7438) }\end{array}$ & $\begin{array}{l}\text { Philippines } \\
\text { (4257) }\end{array}$ \\
\hline $\begin{array}{c}\text { Mongolia } \\
(7346)\end{array}$ & $\begin{array}{c}\text { United Arab } \\
\text { Emirates (3519) }\end{array}$ & $\begin{array}{l}\text { Mongolia } \\
\text { (12844) }\end{array}$ & $\begin{array}{l}\text { Cuba } \\
\text { (7811) }\end{array}$ & $\begin{array}{c}\text { Mongolia } \\
(8066)\end{array}$ & $\begin{array}{c}\text { East Timor } \\
(7145)\end{array}$ & $\begin{array}{c}\text { Mongolia } \\
(7334)\end{array}$ & $\begin{array}{l}\text { East Timor } \\
(4206)\end{array}$ \\
\hline $\begin{array}{l}\text { Norway } \\
(5855)\end{array}$ & $\begin{array}{l}\text { Niger } \\
(3429)\end{array}$ & $\begin{array}{l}\text { Norway } \\
(10033)\end{array}$ & $\begin{array}{c}\text { Philippines } \\
\text { (7714) }\end{array}$ & $\begin{array}{l}\text { Norway } \\
(6064)\end{array}$ & $\begin{array}{l}\text { Cuba } \\
(7057)\end{array}$ & $\begin{array}{l}\text { Norway } \\
(5569)\end{array}$ & $\begin{array}{l}\text { Cuba } \\
(4127)\end{array}$ \\
\hline $\begin{array}{l}\text { Finland } \\
(5619)\end{array}$ & $\begin{array}{c}\text { Burkina Faso } \\
(3365)\end{array}$ & $\begin{array}{c}\text { Kazakhstan } \\
(9690)\end{array}$ & $\begin{array}{c}\text { Bangladesh } \\
(7155)\end{array}$ & $\begin{array}{c}\text { Kazakhstan } \\
(6022)\end{array}$ & $\begin{array}{c}\text { Costa Rica } \\
(6906)\end{array}$ & $\begin{array}{c}\text { Kazakhstan } \\
(5519)\end{array}$ & $\begin{array}{c}\text { Costa Rica } \\
\text { (4035) }\end{array}$ \\
\hline $\begin{array}{l}\text { Russia } \\
(5606)\end{array}$ & $\begin{array}{l}\text { Oman } \\
(3364)\end{array}$ & $\begin{array}{l}\text { Finland } \\
(9630)\end{array}$ & $\begin{array}{c}\text { Sierra Leone } \\
(6995)\end{array}$ & $\begin{array}{l}\text { Russia } \\
(5867)\end{array}$ & $\begin{array}{c}\text { Panama } \\
(6849)\end{array}$ & $\begin{array}{l}\text { Russia } \\
(5505)\end{array}$ & $\begin{array}{l}\text { Panama } \\
(4025)\end{array}$ \\
\hline $\begin{array}{c}\text { Kazakhstan } \\
\text { (5589) }\end{array}$ & $\begin{array}{l}\text { Sudan } \\
(3313)\end{array}$ & $\begin{array}{l}\text { Russia } \\
(9623)\end{array}$ & $\begin{array}{c}\text { Haiti } \\
\text { (6966) }\end{array}$ & $\begin{array}{l}\text { Finland } \\
\text { (5851) }\end{array}$ & $\begin{array}{c}\text { Indonesia } \\
(6794)\end{array}$ & $\begin{array}{l}\text { Finland } \\
(5450)\end{array}$ & $\begin{array}{l}\text { Indonesia } \\
(4006)\end{array}$ \\
\hline $\begin{array}{l}\text { Canada } \\
(5357)\end{array}$ & $\begin{array}{l}\text { Kuwait } \\
\text { (3290) }\end{array}$ & $\begin{array}{l}\text { Canada } \\
\text { (9191) }\end{array}$ & $\begin{array}{c}\text { Burkina Faso } \\
(6859)\end{array}$ & $\begin{array}{c}\text { Tajikistan } \\
(5762)\end{array}$ & $\begin{array}{c}\text { Sri-Lanka } \\
(6768)\end{array}$ & $\begin{array}{c}\text { Canada } \\
(5164)\end{array}$ & $\begin{array}{c}\text { Sri-Lanka } \\
(3987)\end{array}$ \\
\hline $\begin{array}{c}\text { Tajikistan } \\
\text { (5271) }\end{array}$ & $\begin{array}{l}\text { Mali } \\
\text { (3221) }\end{array}$ & $\begin{array}{c}\text { Tajikistan } \\
(9164)\end{array}$ & $\begin{array}{c}\text { Guinea-Bissau } \\
(6760)\end{array}$ & $\begin{array}{l}\text { Canada } \\
(5576)\end{array}$ & $\begin{array}{l}\text { Haiti } \\
(6700)\end{array}$ & $\begin{array}{c}\text { Tajikistan } \\
(5067)\end{array}$ & $\begin{array}{l}\text { Haiti } \\
(3949)\end{array}$ \\
\hline $\begin{array}{c}\text { Switzerland } \\
(5148)\end{array}$ & $\begin{array}{c}\text { Guinea-Bissau } \\
(3176)\end{array}$ & $\begin{array}{c}\text { Switzerland } \\
(8758)\end{array}$ & $\begin{array}{c}\text { Sri-Lanka } \\
(6745)\end{array}$ & $\begin{array}{c}\text { Switzerland } \\
(5237)\end{array}$ & $\begin{array}{c}\text { Sierra Leone } \\
(6685)\end{array}$ & $\begin{array}{c}\text { Estonia } \\
(4827)\end{array}$ & $\begin{array}{l}\text { Sierra Leone } \\
\quad(3927)\end{array}$ \\
\hline $\begin{array}{l}\text { Estonia } \\
(5042)\end{array}$ & $\begin{array}{l}\text { Somalia } \\
(3169)\end{array}$ & $\begin{array}{l}\text { Estonia } \\
\text { (8621) }\end{array}$ & $\begin{array}{l}\text { Senegal } \\
(6716)\end{array}$ & $\begin{array}{l}\text { Estonia } \\
(5201)\end{array}$ & $\begin{array}{l}\text { Liberia } \\
(6567)\end{array}$ & $\begin{array}{l}\text { Switzerland } \\
(4815)\end{array}$ & $\begin{array}{l}\text { Liberia } \\
(3872)\end{array}$ \\
\hline
\end{tabular}


Figures 1 and 2 reflect a heat map of the world distribution for heating and cooling degree days, using as a reference temperature Tref $=65^{\circ} \mathrm{F}$.

Additional insight is provided through a comparison of the effects of climatic factors by studying the percentage changes in CDD and HDD among the temperature-based indices, and the various thermal comfort indices in both ${ }^{\circ} \mathrm{F}$ and ${ }^{\circ} \mathrm{C}$. Figure 3 reflects the variation in degree days among the temperaturebased degree days and other thermal comfort indices. The average values of the indices for the period 1964-2013, on a global average basis are shown. There is a noted difference between the effects on HDDs and CDDs.

For the heating degree days, both the ESI and HUM show fewer degree days when compared to temperature-based indices. For the ESI, the disparity increases with the increase in the reference temperature ranging from $-6 \%$ at $15.6^{\circ} \mathrm{C}$ to $-15 \%$ at $21.1^{\circ} \mathrm{C}$, while $\mathrm{HUM}$ values are always constant at around $-19 \%$. The difference between the Temp_HDD and the HUM_HDD seems marginal between $2 \%$ to $4 \%$ for all references.

For the cooling degree days, the difference between the degree days of the various indices and the temperature-based one is more pronounced. All the indices seem to add more cooling degree days when compared to those generated by the base temperatures. In that context, the heat index displays the lowest variability ranging between $23 \%$ to $30 \%$, while the Humidex reflects the highest increase ranging between $92 \%$ and $145 \%$.

Adding humidity and solar radiation does have an effect on the computed value of degree days, and by proxy the actual energy consumed for space heating and cooling control in the residential and commercial sectors. These combined effects seem to vary depending on the index used and whether the purpose is for heating or cooling.
Looking at the ESI and HI, we can assess that the effect on CDD of adding humidity using the $\mathrm{HI}$ is between $6 \%$ to $15 \%$, and the combined effect of humidity and solar radiation is $16 \%$ to $44 \%$, using the ESI for the average period 1964-2013. For the HDD, humidity alone seems not to have an impact ( $\max 4 \%$ ), while the combined effect of humidity and solar radiation seems to decrease the number of HDD by up to $15 \%$ at $\operatorname{Tref} 17.2^{\circ} \mathrm{C}\left(70^{\circ} \mathrm{F}\right)$.

Intuitively, on a country level, the most affected nations seem to be the ones that include the largest resident population with the highest humidity levels and solar radiations. Table 3 identifies the top five countries with the highest positive variation in degree days for each index.

Nevertheless, this illustrative approach has its own limitation as it cannot be firmly concluded that the difference between the temperature-based index and the thermal comfort indices are solely due to climatic factors. Biases can arise from the definition of thermal indicators or can result from the calibration process. We encourage potential users to propose other indices that may be complementary to our methodology and would enrich the dataset.

\section{Benchmarking against existing datasets}

The database has been compared with other available databases that were calculated either on a regional or global level using a similar computation method for degree days, as outlined in Appendix 1 but with varying metadata sources and spatial or temporal aggregations. Comparisons for selected countries were based on national (EIA, 2012 and Vesma, 2014), regional (Eurostat, 2011) and global databases (World Resource Institute, 2003 and Wheeler, 2012). These comparisons were only for the temperature-based degree days, as there is a limited source identified for reviewing degree days generated from other thermal comfort indices. 

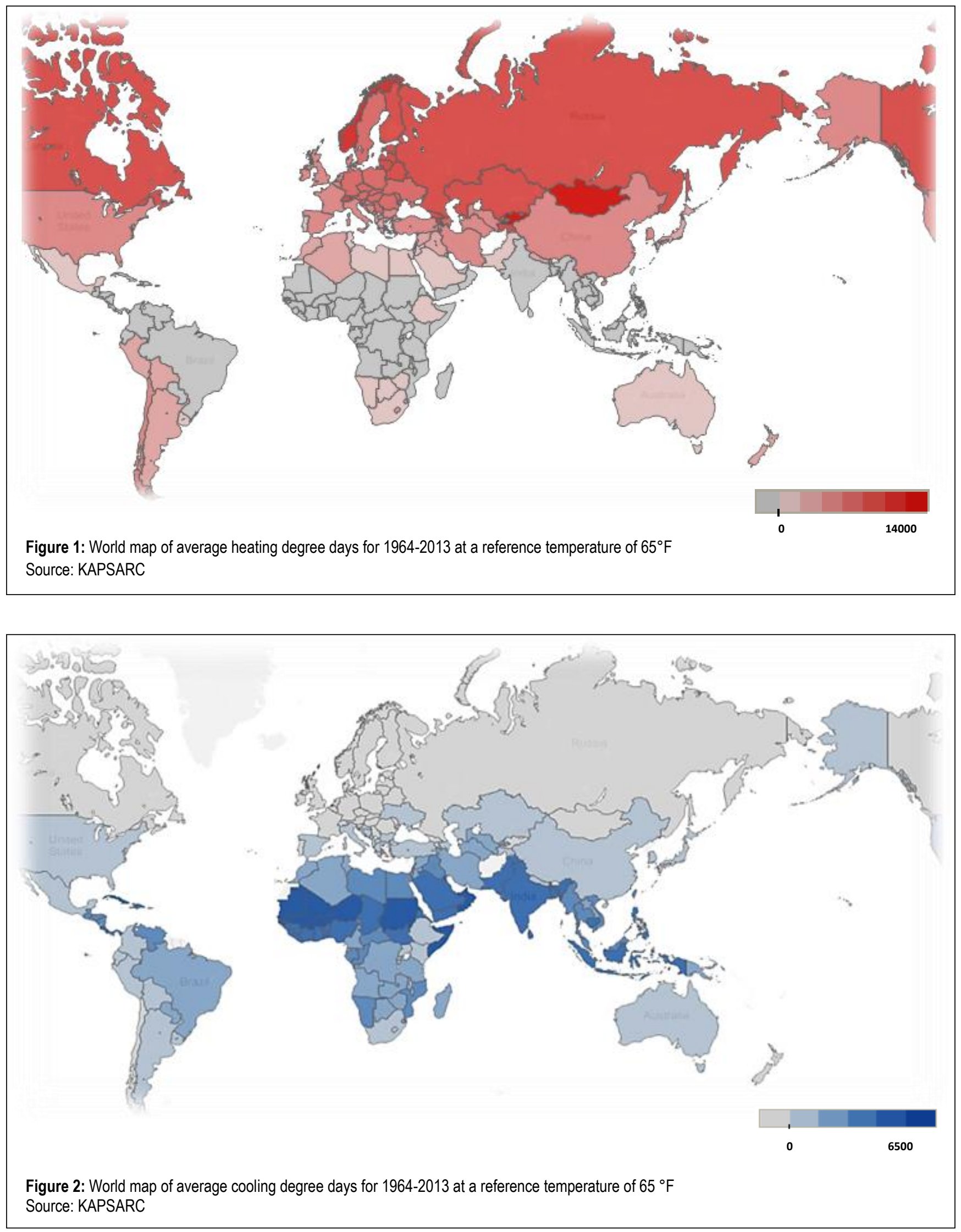


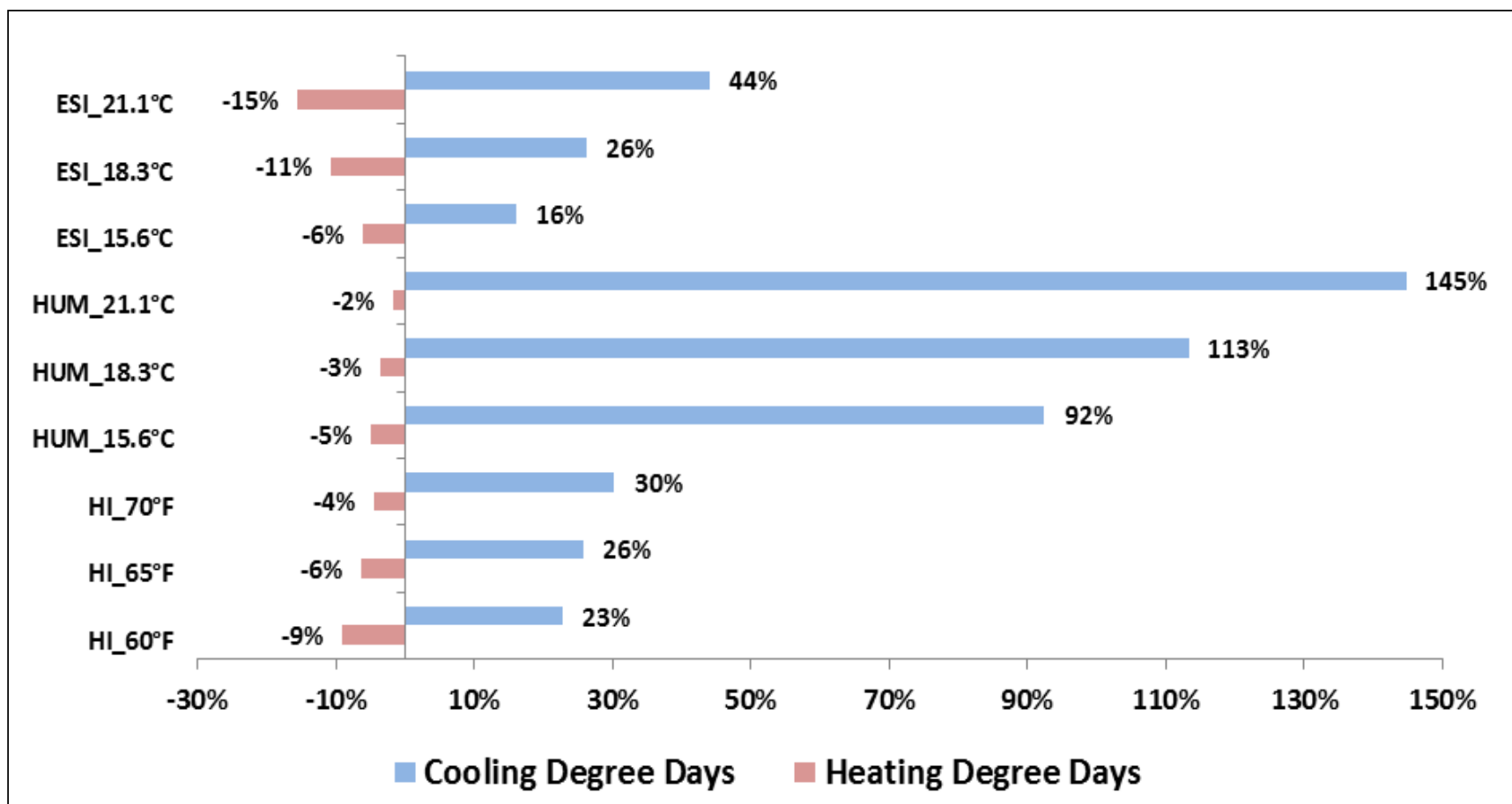

Figure 3: Global average of degree days variation between temperature-based and thermal comfort indices for HDD and CDD at various reference temperatures. Source: KAPSARC

\begin{tabular}{|c|c|c|c|c|c|}
\hline \multicolumn{2}{|c|}{ Heat Index } & \multicolumn{2}{|c|}{ Humidex } & \multicolumn{2}{|c|}{ ESI } \\
\hline HDD & CDD & HDD & CDD & HDD & CDD \\
\hline Niger (58) & Cuba (2445) & Kyrgyz Rep. (829) & Philippines (4552) & Niger (74) & Malaysia (1570) \\
\hline Mali (35) & East Timor (2428) & Mongolia (720) & Indonesia (4530) & Burkina Faso (57) & Indonesia (1479) \\
\hline Burkina Faso (29) & Philippines (2421) & Tajikistan (492) & Panama (4510) & Mali (52) & $\begin{array}{l}\text { Equatorial Guinea } \\
\qquad(1437)\end{array}$ \\
\hline Mauritania (27) & Bangladesh (2352) & Kazakhstan (433) & Costa Rica (4502) & Mauritania (43) & Panama (1423) \\
\hline Chad (24) & Indonesia (2066) & Russia (261) & Malaysia (4474) & Chad (30) & Liberia (1405) \\
\hline $\begin{array}{l}\text { Table 3: Top } 5 \text { co } \\
\text { indices for the avera } \\
\text { Source: KAPSARC }\end{array}$ & $\begin{array}{l}\text { s with the highest } p \\
1964-2013 \text { at } 18.3^{\circ}\end{array}$ & $\begin{array}{l}\text { e change in degre } \\
\text { equivalent. }\end{array}$ & ys between various & & nd thermal comfort \\
\hline
\end{tabular}


Table 4 reflects a comparison between the CMCCKASPARC database and other regional or global databases available in the literature. Results show varying percentages and level differences on a country basis for both cooling and heating degree days. The details of the comparison procedure are found in Appendix 3.

\begin{tabular}{|c|c|c|c|c|c|c|}
\hline Country & Source & Period & Tref & HDD (\%) & CDD (\%) & Note \\
\hline \multirow[t]{2}{*}{ USA } & EIA & 1949-2011 & $65^{\circ} \mathrm{F}$ & $803(15 \%)$ & $70(4 \%)$ & $\begin{array}{l}\text { Alaska and Hawaii values were added to EIA's value, ground based data from } \\
\qquad 200 \text { stations }\end{array}$ \\
\hline & WRI & 1977-1991 & $18^{\circ} \mathrm{C}$ & $758(26 \%)$ & $-117(-16 \%)$ & WRI data accounts for $99.7 \%$ of the country, station based data. \\
\hline \multirow{5}{*}{ UK } & Vesma & 1993-2013 & $15.5^{\circ} \mathrm{C}$ & $-71(-3.2 \%)$ & $35(18 \%)$ & Data was adjusted for $0.1^{\circ} \mathrm{C}$, ground based, regional level aggregation \\
\hline & Vesma & 1993-2013 & $18.5^{\circ} \mathrm{C}$ & $-207(-6.8 \%)$ & - & Data was adjusted for $0.3^{\circ} \mathrm{C}$, ground regional level \\
\hline & Eurostat & 1980-2009 & $18^{\circ} \mathrm{C}$ & $8(0.3 \%)$ & - & Data was adjusted for heating threshold, ground based NTUS 2 regional level \\
\hline & WRI & 1977-1991 & $18^{\circ} \mathrm{C}$ & $289(9 \%)$ & $9(13 \%)$ & WRI data accounts for $92.2 \%$ of the country, station based data. \\
\hline & Wheeler (2012) & 1980-2011 & $65^{\circ} \mathrm{F}$ & $134(2 \%)$ & $91(70 \%)$ & $2.5^{\circ *} 2.5^{\circ}$ grid, various pop weighting and daily average \\
\hline \multirow{3}{*}{ Turkey } & Eurostat & 1980-2009 & $18^{\circ} \mathrm{C}$ & $834(24 \%)$ & - & Adjusted for heating threshold, ground based NTUS 2 regional level \\
\hline & WRI & 1977-1991 & $18^{\circ} \mathrm{C}$ & $1148(36 \%)$ & $21(3 \%)$ & WRI data accounts for $64.6 \%$ of the country area, station based data.. \\
\hline & Wheeler (2012) & 1980-2011 & $65^{\circ} \mathrm{F}$ & $67(1 \%)$ & $741(62 \%)$ & $\mathrm{N} / \mathrm{A}$ \\
\hline \multirow{2}{*}{ Argentina } & WRI & 1977-1991 & $18^{\circ} \mathrm{C}$ & $449(30 \%)$ & $82(8 \%)$ & WRI data accounts for $99.7 \%$ of the country's area, station based data. \\
\hline & Wheeler (2012) & 1980-2011 & $65^{\circ} \mathrm{F}$ & $1045(34 \%)$ & $-10(-1 \%)$ & N/A \\
\hline \multirow{2}{*}{ Brazil } & WRI & 1977-1991 & $18^{\circ} \mathrm{C}$ & $74(39 \%)$ & $-372(-23 \%)$ & WRI data accounts for $89.8 \%$ of the country's area, station based data. \\
\hline & Wheeler (2012) & 1980-2011 & $65^{\circ} \mathrm{F}$ & $166(43 \%)$ & $-53(-2 \%)$ & $\mathrm{N} / \mathrm{A}$ \\
\hline \multirow{2}{*}{ China } & WRI & 1977-1991 & $18^{\circ} \mathrm{C}$ & $523(19 \%)$ & $-2387(-29 \%)$ & WRI data accounts for $97.50 \%$ of the country's area, station based data. \\
\hline & Wheeler (2012) & 1980-2011 & $65^{\circ} \mathrm{F}$ & $-191(-4 \%)$ & $367(26 \%)$ & N/A \\
\hline \multirow{3}{*}{ France } & WRI & 1977-1991 & $18^{\circ} \mathrm{C}$ & $667(21 \%)$ & $-2.3(-1 \%)$ & WRI data accounts for $68.5 \%$ of the country, station based data. \\
\hline & Eurostat & 1980-2009 & $18^{\circ} \mathrm{C}$ & $802(25 \%)$ & - & Data was adjusted for heating threshold, ground based NTUS 2 regional level \\
\hline & Wheeler (2012) & 1980-2011 & $65^{\circ} \mathrm{F}$ & $48(1 \%)$ & $255(55 \%)$ & $\mathrm{N} / \mathrm{A}$ \\
\hline \multirow{3}{*}{ Germany } & WRI & 1977-1991 & $18^{\circ} \mathrm{C}$ & $671(17 \%)$ & $23(16 \%)$ & WRI data accounts for $100 \%$ of the country, station based data. \\
\hline & Eurostat & 1980-2009 & $18^{\circ} \mathrm{C}$ & $801(20 \%)$ & - & Adjusted for heating threshold, ground based NTUS 2 regional level \\
\hline & Wheeler (2012) & 1980-2011 & $65^{\circ} \mathrm{F}$ & $-568(-8 \%)$ & $260(84 \%)$ & N/A \\
\hline \multirow{2}{*}{ Kazakhstan } & WRI & 1977-1991 & $18^{\circ} \mathrm{C}$ & $875(16 \%)$ & $49(9 \%)$ & WRI data accounts for $98.10 \%$ of the country's area, station based data. \\
\hline & Wheeler (2012) & 1980-2011 & $65^{\circ} \mathrm{F}$ & $-1068(-11 \%)$ & $730(82 \%)$ & $\mathrm{N} / \mathrm{A}$ \\
\hline \multirow{2}{*}{ Russia } & WRI & 1977-1991 & $18^{\circ} \mathrm{C}$ & $287(5 \%)$ & $36(16 \%)$ & WRI data accounts for $84.40 \%$ of the country's area, station based data. \\
\hline & Wheeler (2012) & 1980-2011 & $65^{\circ} \mathrm{F}$ & $-577(-6 \%)$ & $328(75 \%)$ & N/A \\
\hline \multirow{2}{*}{$\begin{array}{l}\text { Saudi } \\
\text { Arabia }\end{array}$} & WRI & 1977-1991 & $18^{\circ} \mathrm{C}$ & $255(45 \%)$ & $-159(-5 \%)$ & WRI data accounts for $56.90 \%$ of the country's area, station based data. \\
\hline & Wheeler (2012) & 1980-2011 & $65^{\circ} \mathrm{F}$ & $51(5 \%)$ & $2159(40 \%)$ & N/A \\
\hline \multirow{3}{*}{ Spain } & WRI & 1977-1991 & $18^{\circ} \mathrm{C}$ & $1054(42 \%)$ & $-91(-15 \%)$ & WRI data accounts for $91.10 \%$ of the country's area, station based data. \\
\hline & Eurostat & 1980-2009 & $18^{\circ} \mathrm{C}$ & $947(34 \%)$ & - & Data was adjusted fo heating threshold, ground based NTUS 2 regional level \\
\hline & Wheeler (2012) & 1980-2011 & $65^{\circ} \mathrm{F}$ & $1456(31 \%)$ & $337(30 \%)$ & N/A \\
\hline \multirow{3}{*}{ Sweden } & WRI & 1977-1991 & $18^{\circ} \mathrm{C}$ & $153(3 \%)$ & $29(39 \%)$ & WRI data accounts for $87.90 \%$ of the country's area, station based data. \\
\hline & Eurostat & 1980-2009 & $18^{\circ} \mathrm{C}$ & $-926(-21 \%)$ & - & Data was adjusted fo heating threshold, ground based NTUS 2 regional level \\
\hline & Wheeler (2012) & 1980-2011 & $65^{\circ} \mathrm{F}$ & $347(4 \%)$ & $115(79 \%)$ & $\mathrm{N} / \mathrm{A}$ \\
\hline \multirow{2}{*}{$\begin{array}{l}\text { United Arab } \\
\text { Emirates }\end{array}$} & WRI & 1977-1991 & $18^{\circ} \mathrm{C}$ & $296(99 \%)$ & $303(8 \%)$ & WRI data accounts for $90.30 \%$ of the country's area, station based data. \\
\hline & Wheeler (2012) & 1980-2011 & $65^{\circ} \mathrm{F}$ & $273(47 \%)$ & $2146(34 \%)$ & N/A \\
\hline \multirow{2}{*}{ Japan } & WRI & 1977-1991 & $18^{\circ} \mathrm{C}$ & $260(12 \%)$ & $-263(-42 \%)$ & WRI data accounts for $100 \%$ of the country's area, station based data. \\
\hline & Wheeler (2012) & 1980-2011 & $65^{\circ} \mathrm{F}$ & $1107(28 \%)$ & $-233(-22 \%)$ & $N / A$ \\
\hline
\end{tabular}




\section{Conclusion}

Despite the widespread usage of degree days, there is limited access to global databases that enable comparisons between countries. The newly created CMCC-KAPSARC database provides a reliable tool for the purpose of seasonal adjustments of energy demand on both regional and national levels. Paralleled to existing available databases, it offers an important contribution by increasing the geographical coverage, the number of reference temperatures, the timespan, and the temporal granularity. Furthermore, the availability of degree days that include additional climatic factors - such as humidity and solar radiation-allows finer judgment of the policy impacts of energy productivity and intensity targets. However, in a world of energy productivity/intensity targets for addressing climate change, KAPSARC's new dataset assists in providing unbiased comparisons between countries at a level of granularity not seen before. Furthermore, the time series data allows inter-temporal comparisons of the performance for individual countries to judge the impacts of policies designed to improve productivity over time. 


\section{Appendix 1: Defining the thermal comfort indices}

When used for energy-related applications, the degree days methodology is defined in terms of Cooling Degree Days (CDD) and Heating Degree Days (HDD). A degree day is calculated as the difference between a reference temperature (Tref) and the average of the maximum and minimum temperature (Tmean). If the difference is positive it is counted as HDD, if it is negative it is represented as CDD. CDD and HDD can be computed for various periods (i) by summing up the daily values in the form of:

$H D D i=\sum_{\mathrm{o} \text { days }}^{i \text { days }}\left(\mathrm{T}_{\text {ref }-} \mathrm{T}_{\text {daily mean }}\right)$

$C D D i=\sum_{\mathrm{o} \text { days }}^{i \text { days }}\left(\mathrm{T}_{\text {dialy mean }}-\mathrm{T}_{\text {ref }}\right)$

Values for CDD and HDD are typically summed on a monthly or yearly basis, with the most commonly used reference temperature being $65^{\circ} \mathrm{F}\left(18^{\circ} \mathrm{C}\right)$. Power generation and utility companies tend to implement the methodology on a higher frequency, to the scale of hours or minutes to monitor or forecast potential load fluctuations.

\section{Heat index $(H I)$ :}

We used the heat index as defined by Rothfusz et al (1990) and modified by the US-based Climate Protection Center (CPC) of the National Oceanographic and Atmospheric Administration (NOAA). It is defined as a function of air temperature and relative humidity as follows:

$H I=-42.38+2.05 . T+10.14 \cdot R H-0.22 . T \cdot R H-6.84 \times 10^{-3} \cdot T^{2}-5.48 \times 10^{-2} \cdot R H^{2}+1.23 \times 10^{-3} \cdot T^{2} \cdot R H+8.53 \times 10^{-4} \cdot T \cdot R H^{2}$

$-1.99 \times 10^{-6} \cdot T^{2} \cdot R H^{2}$

Where $\mathrm{T}$ equals the ambient dry bulb temperature in ${ }^{\circ} \mathrm{F}$ and $\mathrm{RH}$ is equivalent to the relative humidity in percentage terms with a stated error of $\pm 1.3^{\circ} \mathrm{F}$ the heat index is to be considered within some boundaries. In particular, it can be thought as optimal for temperatures above $80 \mathrm{~F}$ and relative humidity above $40 \%$. The Climate Prediction Center (CPC) at the National Oceanic and Atmospheric Administration (NOAA) made some conditional adjustments to the original equation to refine and extend the range of the index outside the above stated boundaries, these include:

For $R H<13 \%$ and $80^{\circ} \mathrm{F}<\mathrm{T}<112^{\circ} \mathrm{F}$

$$
H I_{\text {adjusted }}=H I-\left[\frac{(13-R H)}{4}\right] \times \sqrt{\left[17-\frac{A b s(T-95)}{17}\right]}
$$

For $R H>85 \%$ and $80^{\circ} \mathrm{F}<\mathrm{T}<87^{\circ} \mathrm{F}$

$$
H I_{\text {adjusted }}=H I+\left[\frac{(R H-85)}{10}\right] \times\left[\frac{87-T}{5}\right]
$$


More generally if, when using equation (3) above, the resulting HI for any combination of $\mathrm{T}$ and $\mathrm{RH}$ is below 80 F, the Rothfusz regression is replaced by Steadman's (1979) formula expressed in the form of:

$$
H I=0.5 \times[\mathrm{T}+61+1.2 \times(\mathrm{T}-68)+0.094 \times R H
$$

The above mentioned Heat Index (HI) has been calculated using NOAA's source code and has Fahrenheit as a unit.

\section{Humidex (HUM):}

The Meteorological Agency of Canada developed the Humidex, a thermal comfort index which was also considered in this paper. It aims at reflecting the human perceived temperature by incorporating the effect of humidity into the thermal comfort index by looking at the dew point temperature. The index was first defined by Richardson et al, (1979) and is calculated using the following equation:

$$
H U M=T+0.5555 \times\left(6.11 \times e^{5417.7530 \times\left(\frac{1}{273.16}-\frac{1}{T d e W}\right)}-10\right)
$$

With $\mathrm{T}$ being the air temperature in ${ }^{\circ} \mathrm{C}$ and $T_{\text {dew }}$ the dew point temperature in Kelvin as defined below, that can be derived from the relative humidity using equation 8 below.

$T_{\text {dew }}=T-\frac{100-R H}{5}$

where $\mathrm{RH}$ is the relative humidity in percentage terms. When compared to the Heat Index, the Humidex typically yields higher values at equal temperatures and relative humidity values, something that will be noticed in the ensuing comparison of degree-days generated by indices. The Humidex is most commonly expressed in Celsius.

\section{Environmental Stress Index (ESI):}

The Environmental Stress Index (ESI) was developed by Moran et al (2001) as a substitute and proxy for the wet-bulb temperature-based index. It is an experimental index and adds solar radiation as an additional parameter to temperature and relative humidity:

$E S I=0.63 \times T-0.03 \times R H+0.002 \times S R+0.0054 \times(T \times R H)-0.073 \times(0.1+S R)^{-1}$

With $T$ being the ambient temperature in ${ }^{\circ} \mathrm{C}$ and $R H$ the relative humidity in percentage terms and $S R$ the solar radiation in $\mathrm{W} / \mathrm{m} 2$ touching the surface at a vertical angle of $90^{\circ}$. This index has been validated for various climatic conditions such as hot/dry and hot/wet (Moran, 2006) and forms an interesting approach for incorporating the three climatic variables into a thermal comfort index.

This section represents the descriptive statistics of various indices. Table 5 below represents the correlation coefficient, mean, median, standard deviation, kurtosis, skewness and coefficient of variation for the heating and cooling degree days' time series derived from the various thermal comfort indices at three different reference temperatures for the mean of the period 1964-2013. 


\section{Appendix 2: Descriptive statistics of various indices}

This section represents the descriptive statistics of various indices. Table 5 below represents the correlation coefficient, mean, median, standard deviation, kurtosis, skewness and coefficient of variation for the heating and cooling degree days' time series derived from the various thermal comfort indices at three different reference temperatures for the mean of the period 1964-2013.

\begin{tabular}{|c|c|c|c|c|c|c|c|c|c|c|c|c|c|c|}
\hline \multirow[b]{2}{*}{ Index } & \multirow[b]{2}{*}{ Tref } & \multirow[b]{2}{*}{ Correlation } & \multicolumn{6}{|c|}{ HDD } & \multicolumn{6}{|c|}{ CDD } \\
\hline & & & Mean & Median & $\begin{array}{l}\text { Standard } \\
\text { Deviation }\end{array}$ & Kurtosis & Skewness & $\begin{array}{l}\text { Coef of } \\
\text { Variation }\end{array}$ & Mean & Median & $\begin{array}{l}\text { Standard } \\
\text { Deviation }\end{array}$ & Kurtosis & Skewness & $\begin{array}{l}\text { Coef of } \\
\text { Variation }\end{array}$ \\
\hline \multirow{3}{*}{ Temp_C } & $15.6^{\circ} \mathrm{C}$ & 0.79 & 1,316 & 531 & 1,585 & 0.56 & 1.15 & 1.20 & 1,962 & 1,801 & 1,367 & $(1.37)$ & 0.23 & 0.70 \\
\hline & $18.3^{\circ} \mathrm{C}$ & 0.77 & 1,714 & 855 & 1,882 & $(0.08)$ & 0.95 & 1.10 & 1,374 & 1,222 & 1,074 & $(1.18)$ & 0.42 & 0.78 \\
\hline & $21.1^{\circ} \mathrm{C}$ & 0.72 & 2,229 & 1,337 & 2,184 & $(0.50)$ & 0.77 & 0.98 & 867 & 683 & 770 & $(0.60)$ & 0.74 & 0.89 \\
\hline \multirow{3}{*}{ Temp_F } & $60^{\circ} \mathrm{F}$ & 0.79 & 2,358 & 948 & 2,845 & 0.58 & 1.15 & 1.21 & 3,551 & 3,267 & 2,470 & $(1.37)$ & 0.22 & 0.70 \\
\hline & $65^{\circ} \mathrm{F}$ & 0.77 & 3,095 & 1,548 & 3,394 & $(0.08)$ & 0.94 & 1.10 & 2,462 & 2,190 & 1,927 & (1.18) & 0.42 & 0.78 \\
\hline & $70^{\circ} \mathrm{F}$ & 0.72 & 4,016 & 2,410 & 3,932 & $(0.50)$ & 0.77 & 0.98 & 1,557 & 1,226 & 1,384 & $(0.60)$ & 0.74 & 0.89 \\
\hline \multirow{3}{*}{$\begin{array}{l}\text { Heat } \\
\text { Index }\end{array}$} & $57.56^{\circ} \mathrm{F}$ & 0.79 & 2,145 & 835 & 2,636 & 0.86 & 1.22 & 1.23 & 4,356 & 3,791 & 3,006 & $(1.41)$ & 0.22 & 0.69 \\
\hline & $63.08^{\circ}$ & 0.79 & 2,899 & 1,468 & 3,237 & 0.05 & 0.98 & 1.12 & 3,093 & 2,382 & 2,410 & $(1.31)$ & 0.38 & 0.78 \\
\hline & $68.58^{\circ}$ & 0.77 & 3,839 & 2,332 & 3,851 & $(0.47)$ & 0.78 & 1.00 & 2,024 & 1,457 & 1,782 & $(1.10)$ & 0.58 & 0.88 \\
\hline \multirow{3}{*}{ Humidex } & $13.98^{\circ} \mathrm{C}$ & 0.78 & 1,253 & 382 & 1,615 & 1.45 & 1.37 & 1.29 & 3,770 & 3,308 & 2,548 & $(1.36)$ & 0.25 & 0.68 \\
\hline & $17.40^{\circ} \mathrm{C}$ & 0.79 & 1,657 & 750 & 1,963 & 0.58 & 1.14 & 1.18 & 2,925 & 2,397 & 2,202 & $(1.27)$ & 0.37 & 0.75 \\
\hline & $21.09^{\circ} \mathrm{C}$ & 0.79 & 2,192 & 1,277 & 2,372 & $(0.09)$ & 0.92 & 1.08 & 2,113 & 1,535 & 1,790 & (1.11) & 0.53 & 0.85 \\
\hline \multirow{3}{*}{ ESI } & $12.60^{\circ} \mathrm{C}$ & 0.80 & 1,237 & 445 & 1,554 & 0.96 & 1.28 & 1.26 & 2,274 & 2,039 & 1,528 & $(1.36)$ & 0.24 & 0.67 \\
\hline & $14.90^{\circ} \mathrm{C}$ & 0.80 & 1,532 & 705 & 1,791 & 0.38 & 1.10 & 1.17 & 1,730 & 1,446 & 1,286 & $(1.27)$ & 0.36 & 0.74 \\
\hline & $17.20^{\circ} \mathrm{C}$ & 0.80 & 1,887 & 1,041 & 2,040 & $(0.06)$ & 0.95 & 1.09 & 1,244 & 935 & 1,026 & (1.11) & 0.51 & 0.82 \\
\hline
\end{tabular}

\section{Appendix 3: Methodology for the comparison of databases}

Table 4 summarizes the results by country, reference temperature, time-span and the average CDD and HDD variations calculated as the mean of the annual variations for the comparative periods.

The reference temperature for the World Resource Institute's database is slightly different than the ones used in this paper, so the CDD and HDD degrees days were recalculated at a reference temperature of $18^{\circ} \mathrm{C}$ and the benchmarking was performed accordingly.

In the case of Vesma, the provided degree days for the United Kingdom used a slightly higher reference temperature (by up to $0.1^{\circ} \mathrm{C}$ ). We adjusted their respective reference temperature by adding or subtracting to their yearly/periodic averages the differences between the reference temperatures multiplied by the number of days in the year. This adjustment had minimal effect on the variation $(+/-2 \%)$ except for the cases where the annual degree days were very minimal $<100$, which can be ignored. 
Eurostat's HDD were calculated using a Tref of $18^{\circ} \mathrm{C}$, but also accounted for a heating threshold equal to $15^{\circ} \mathrm{C}$. This means that HDDs are not accrued for some of the daily mean temperature values that range between $15^{\circ} \mathrm{C}$ and $18^{\circ} \mathrm{C}$. For the purpose of comparison, the relevant time series of the CMCC-KAPSAC dataset were adjusted to Eurostat's by taking the generated degree days at Tref $15.6^{\circ} \mathrm{C}$ and adding a difference of $2.4^{\circ} \mathrm{C}$ over a year. No adjustments were made for the comparisons with the EIA's and Wheeler's datasets.

In order to fully disentangle the effect of spatial and temporal aggregation, a comparison between the CMCC/ KAPSARC dataset and Wheeler (2012) eliminated most of the other effects, The two were similarly computed from re-analysis of satellite data. Furthermore, there was no need to perform any adjustments in the reference temperature, thus limiting potential approximation effects. The difference in the generated degree days was found to be about $29.6 \%$ for HDD and $43.9 \%$ for CDD, when comparing both global averages for 147 countries for 1980-2011. The comparison was done by calculating the difference in net degree days for all countries at $65^{\circ} \mathrm{F}$ as Wheeler (2012) only provides a single reference temperature for his dataset. Detailed country level is provided in Table 4, in the main body of the paper.

The comparison with EIA's US degree days for $1949-2011$ for Tref $65^{\circ} \mathrm{F}$ reflects a minimal deviation for the CDD $(+4 \%)$ and a moderated one for the HDD $(+15 \%)$. Yearly averages also reflect similar trends. The EIA figures are based on data from some 200 ground-based stations sparsely located around the contiguous US (EIA, 2012). As CMCC-KAPSARC's data includes the whole of the country, it was necessary to add to the EIA's additional degree days from Alaska and Hawaii. Alaska's HDD accounted for around $30 \mathrm{HDD}^{\circ} \mathrm{F}$, depending on the year, while Hawaii's was around $0.5 \mathrm{HDD}^{\circ} \mathrm{F}$, once population was weighted. Hawaii accounted for an additional $15 \mathrm{CDD}^{\circ} \mathrm{F}$ while Alaska's impact was negligible (data obtained through the Western Regional Climate Center database, 2014)

Similar results were noticed in comparison with the World Resource Institute (WRI) dataset where HDD's variation was about $+26 \%$ and CDD's equal to $-16 \%$. The difference can be apportioned to the effect of temporal aggregation as the EIA's calculations are based on mean daily temperatures, while our data are based on 4-intraday values. As mentioned before, higher data frequency enables better representation of the actual heating and cooling energy needs. Spatial aggregation may have had an effect, albeit to a lesser extent. This could be the case in the comparison with the WRI, as their dataset is based on a higher number of land-based stations (384).

For the UK, the effect of temporal and spatial aggregation seems to be further mitigated due to smaller areas involved and less temperature variations. Comparing the dataset with WRI's, Vesma (2014) and Eurostat show variations ranging between $-6.8 \%$ to $9 \%\left(-207\right.$ to $\left.+281 \mathrm{HDD}^{\circ} \mathrm{C}\right)$ for the $\mathrm{HDD}$ and +35 to $+111 \mathrm{CDD}^{\circ} \mathrm{C}$.

Another comparison with Eurostat's pool of 25 countries reflects that the CMCC/KAPSARC dataset values are on average 16\% higher. We removed Cyprus, Luxembourg and Malta from the comparison as the CMCC/ KAPSARC database does not include them. The disparity may be due to the fact that Eurostat uses land-based daily mean data at NUTS2 level - a classification of nomenclature of territorial units for statistics into a hierarchical system for dividing up the economic territory of the EU into basic regions-which was interpolated on a grid of $50 \mathrm{~km} \times 50 \mathrm{~km}$. This approach uses a higher spatial resolution but a lower temporal resolution. Another explanation of the difference may be due to the approximation associated with the adjustment of the reference temperatures of the two datasets which can amount to as much as $2.4^{\circ} \mathrm{C}$. Furthermore, it is unclear what population weighting approach Eurostat used. 


\section{References}

Al-Hadhrami, L. M. "Comprehensive review of cooling and heating degree days characteristics over Kingdom of Saudi Arabia." Renewable and Sustainable Energy Reviews 27 (2013): 305-314.

Badescu, Viorel, and Elena Zamfir. "Degree-days, degree-hours and ambient temperature bin data from monthly-average temperatures (Romania)." Energy conversion and management 40.8 (1999): 885-900.

Baumert, Kevin, and Mindy Selman. "Heating and cooling degree days." World resources institute (2003).

Benestad R.E., 2008. Heating degree days, cooling degree days and precipitation in Europe.Norwegian Meteorological Institute report no. 4/2008.

Bigano, Andrea, Francesco Bosello, and Giuseppe Marano. "Energy demand and temperature: a dynamic panel analysis." (2006).

Brode et al, "The Universal Thermal Climate Index UTCI Compared to Ergonomics Standards for Assessing the Thermal Environment", Industrial Health (2013), 51, 16-24.

Center for International Earth Science Information Network (CIESIN), International Food Policy Research Institute (IFPRI) and World Resources Institute (WRI). 2000. Gridded Population of the World (GPW), Version 3 [online data]. Palisades, NY: CIESIN, Columbia University. Available at http://sedac.ciesin.columbia.edu/plue/gpw, retrieved March, 2014

De Cian, Enrica, Elisa Lanzi, and Roberto Roson. "Seasonal temperature variations and energy demand." Climatic change 116.3-4 (2013): 805-825.

Dombayc1, Ö. Altan. "Degree-days maps of Turkey for various base temperatures." Energy 34.11 (2009): 1807-1812.
EIA, US. "Annual energy review." Energy Information Administration, US Department of Energy: Washington, DC www. eia. doe. gov/emeu/ aer (2012).

Environment Protection Agency, “ Home Helps. Strategies for Personal Comfort, Staying Healthy,Saving Money,The Environment" Accessed through http://www.epa.gov/region7/citizens/pdf/ EPA_HomeHelps.pdf.

Epstein, Yoram, and Daniel S. Moran. "Thermal comfort and the heat stress indices." Industrial health 44.3 (2006): 388-398.

Eurostat (2011), Energy statistics - heating degreedays, available on http://epp.eurostat.ec.europa.eu/ cache/ITY_SDDS/EN/nrg_esdgr_esms.htm accessed October 2014

Fels, Margaret F. "PRISM: an introduction." Energy and Buildings 9.1 (1986): 5-18.

G. Kopp, Greg; J. Lean (2011). "A new, lower value of total solar irradiance: Evidence and climate significance". Geophys. Res. Lett. 38: L01706

Kalnay et al.,The NCEP/NCAR 40-year reanalysis project, Bull. Amer. Meteor. Soc., 77, 437-470, 1996. Accessed through http://www.esrl.noaa.gov/ $\mathrm{psd} /$ data/gridded/data.ncep.reanalysis.html on March 15th, 2014.

Matzarakis, Andreas, and Christos Balafoutis. "Heating degree $\square$ days over Greece as an index of energy consumption." International Journal of Climatology 24.14 (2004): 1817-1828

Moran, Daniel S., et al. "An environmental stress index (ESI) as a substitute for the wet bulb globe temperature (WBGT)." Journal of thermal biology 26.4 (2001): 427-431. 
Olonscheck, Mady, Anne Holsten, and Jürgen P. Kropp. "Heating and cooling energy demand and related emissions of the German residential building stock under climate change." Energy Policy 39.9 (2011): 4795-4806.

Richardson, F.A. and Canada-Service de l'environnement atmosphérique, Humidex: a method of quantifying human discomfort due to excessive heat and humidity. Downsview, Ont.: Atmospheric Environment, 1979.

Rothfusz, Lans P., and NWS Southern Region Headquarters. "The heat index equation (or, more than you ever wanted to know about heat index)." Fort Worth, Texas: National Oceanic and Atmospheric Administration, National Weather Service, Office of Meteorology (1990): 90-23.

UNEP and Center for International Earth Science Information Network (CIESIN), Africa-Asia-Latin America - Global Population Distribution Databases
(UNEP/GRID-Sioux Falls, Sioux Falls, SD, 2004); available at www.na.unep.net/datasets/datalist.php , retrieved March 2014.

Vesma.com, database of Twenty-year average heating and cooling degree days for UK regions, available at http://www.vesma.com/downloads/ uk_20year.xls, accessed October 2014.

Wheeler, David. "Energy+ Country Performance Ratings, 2001-2010." Available at SSRN 2226485 (2012).

Western Regional Climate Center, Alaska and Hawaii historical heating degree days, Desert Research Institute (DRI), available http:// www.wrcc.dri.edu/ accessed October 2014.

You, Qinglong, et al. "Present and projected degree days in China from observation, reanalysis and simulations." Climate Dynamics (2013): 1-14. 


\section{Database extracts}

A sample of tables that include degree days averages for 1964-2013, generated from multiple thermal indices at various temperatures.

The complete CMCC-KAPSARC database can be accessed at:

http://www.kapsarc.org/en/Documents/KAPSARC-CMCC\%

20Enhanced $\% 20$ Degree $\% 20$ Days $\% 20 \% 20$ Database $\%$

20March\%202015.xlsx 


\begin{tabular}{|c|c|c|c|c|c|c|c|c|c|c|c|c|c|c|c|}
\hline $\begin{array}{c}\text { CDD } \\
\text { Average 1964-2013 }\end{array}$ & $\begin{array}{l}\text { Temp } \\
15.6^{\circ} \mathrm{C}\end{array}$ & $\begin{array}{l}\text { Temp } \\
18.3^{\circ} \mathrm{C}\end{array}$ & $\begin{array}{l}\text { Temp } \\
21.1^{\circ} \mathrm{C}\end{array}$ & $\begin{array}{l}\text { Temp } \\
60^{\circ} \mathrm{F}\end{array}$ & $\begin{array}{l}\text { Temp } \\
65^{\circ} \mathrm{F}\end{array}$ & $\begin{array}{l}\text { Temp } \\
70^{\circ} \mathrm{F}\end{array}$ & $\begin{array}{l}\text { Heat } \\
\text { Index } \\
57.56^{\circ}\end{array}$ & $\begin{array}{c}\text { Heat } \\
\text { Index } \\
63.08^{\circ} \mathrm{F}\end{array}$ & $\begin{array}{c}\text { Heat } \\
\text { Index } \\
68.58^{\circ} \mathrm{F}\end{array}$ & $\begin{array}{l}\text { Humidex } \\
13.98^{\circ} \mathrm{C}\end{array}$ & $\begin{array}{l}\text { Humidex } \\
17.4^{\circ} \mathrm{C}\end{array}$ & $\begin{array}{l}\text { Humidex } \\
21.09^{\circ} \mathrm{C}\end{array}$ & $\begin{array}{c}\text { ESI } \\
12.6^{\circ} \mathrm{C}\end{array}$ & $\begin{array}{c}\text { ESI } \\
14.9^{\circ} \mathrm{C}\end{array}$ & $\begin{array}{c}\text { ESI } \\
17.2^{\circ} \mathrm{C}\end{array}$ \\
\hline Albania & 740 & 420 & 200 & 1343 & 750 & 359 & 1666 & 933 & 436 & 1556 & 1000 & 541 & 939 & 600 & 338 \\
\hline Algeria & 1807 & 1348 & 972 & 3267 & 2418 & 1748 & 3356 & 2382 & 1626 & 2235 & 1578 & 1027 & 1405 & 987 & 659 \\
\hline Angola & 2346 & 1545 & 903 & 4249 & 2765 & 1622 & 5215 & 3481 & 2055 & 4657 & 3529 & 2398 & 2818 & 2081 & 1420 \\
\hline Argentina & 1340 & 862 & 498 & 2428 & 1542 & 895 & 2977 & 1918 & 1126 & 2602 & 1857 & 1201 & 1581 & 1112 & 727 \\
\hline Armenia & 300 & 174 & 94 & 545 & 310 & 168 & 664 & 355 & 177 & 624 & 342 & 157 & 392 & 227 & 117 \\
\hline Australia & 1196 & 714 & 377 & 2169 & 1276 & 676 & 2678 & 1593 & 846 & 2438 & 1642 & 990 & 1460 & 969 & 593 \\
\hline Austria & 226 & 104 & 41 & 412 & 186 & 74 & 587 & 267 & 104 & 694 & 392 & 185 & 418 & 242 & 124 \\
\hline Azerbaijan & 590 & 368 & 211 & 1070 & 658 & 379 & 1261 & 747 & 406 & 1085 & 677 & 362 & 670 & 424 & 241 \\
\hline Bangladesh & 3561 & 2679 & 1822 & 6437 & 4803 & 3274 & 8993 & 7155 & 5426 & 7200 & 6022 & 4802 & 4283 & 3513 & 2772 \\
\hline Belarus & 358 & 183 & 80 & 650 & 326 & 144 & 865 & 434 & 185 & 901 & 540 & 270 & 538 & 324 & 171 \\
\hline Belgium & 415 & 223 & 105 & 754 & 397 & 189 & 979 & 503 & 232 & 992 & 572 & 278 & 594 & 350 & 184 \\
\hline Benin & 3829 & 2890 & 1958 & 6921 & 5182 & 3518 & 8494 & 6565 & 4709 & 7093 & 5893 & 4633 & 4223 & 3430 & 2656 \\
\hline Bolivia & 934 & 572 & 311 & 1693 & 1023 & 558 & 2207 & 1393 & 799 & 2157 & 1557 & 1043 & 1311 & 925 & 614 \\
\hline Bosnia-Herzegovina & 638 & 365 & 187 & 1158 & 653 & 335 & 1457 & 813 & 399 & 1393 & 883 & 475 & 839 & 531 & 300 \\
\hline Botswana & 2178 & 1514 & 978 & 3941 & 2712 & 1757 & 4375 & 2968 & 1822 & 3308 & 2397 & 1539 & 2050 & 1462 & 953 \\
\hline Brazil & 2437 & 1579 & 838 & 4414 & 2824 & 1504 & 5730 & 3892 & 2288 & 5577 & 4379 & 3154 & 3346 & 2562 & 1829 \\
\hline Bulgaria & 757 & 458 & 249 & 1374 & 820 & 447 & 1678 & 989 & 520 & 1519 & 998 & 567 & 921 & 604 & 358 \\
\hline Burkina Faso & 4264 & 3365 & 2494 & 7702 & 6038 & 4483 & 8696 & 6859 & 5137 & 6384 & 5257 & 4102 & 3842 & 3105 & 2401 \\
\hline Burundi & 1123 & 473 & 184 & 2047 & 842 & 329 & 2961 & 1272 & 477 & 3257 & 2031 & 918 & 1885 & 1136 & 564 \\
\hline Cambodia & 3559 & 2586 & 1614 & 6436 & 4634 & 2899 & 8651 & 6647 & 4697 & 7776 & 6528 & 5189 & 4658 & 3821 & 2992 \\
\hline Cameroon & 2557 & 1616 & 844 & 4631 & 2889 & 1514 & 5908 & 3956 & 2180 & 5732 & 4517 & 3226 & 3453 & 2641 & 1847 \\
\hline Canada & 349 & 196 & 97 & 634 & 350 & 173 & 809 & 448 & 218 & 786 & 496 & 274 & 483 & 306 & 176 \\
\hline Central African & 2903 & 1942 & 1062 & 5255 & 3475 & 1906 & 6697 & 4722 & 2833 & 6255 & 5026 & 3718 & 3770 & 2949 & 2140 \\
\hline Chad & 3891 & 2972 & 2083 & 7031 & 5330 & 3743 & 7992 & 6115 & 4344 & 6100 & 4947 & 3764 & 3693 & 2933 & 2211 \\
\hline Chile & 394 & 233 & 120 & 716 & 416 & 216 & 776 & 428 & 207 & 512 & 259 & 104 & 371 & 205 & 96 \\
\hline China & 1230 & 785 & 426 & 2228 & 1404 & 764 & 2987 & 2009 & 1225 & 2856 & 2182 & 1551 & 1717 & 1286 & 911 \\
\hline Colombia & 1503 & 744 & 256 & 2731 & 1325 & 459 & 4007 & 2196 & 941 & 4608 & 3366 & 2124 & 2707 & 1905 & 1223 \\
\hline Costa Rica & 3653 & 2667 & 1645 & 6604 & 4778 & 2953 & 8628 & 6612 & 4603 & 8155 & 6906 & 5558 & 4876 & 4035 & 3195 \\
\hline Cote d'Ivoire & 3404 & 2432 & 1458 & 6155 & 4357 & 2617 & 8042 & 6049 & 4093 & 7446 & 6207 & 4879 & 4468 & 3638 & 2815 \\
\hline Croatia & 620 & 364 & 199 & 1125 & 651 & 357 & 1426 & 810 & 420 & 1383 & 886 & 487 & 832 & 532 & 307 \\
\hline Cuba & 3980 & 2994 & 1974 & 7193 & 5367 & 3545 & 9828 & 7811 & 5804 & 8306 & 7057 & 5709 & 4967 & 4127 & 3287 \\
\hline Czech Rep. & 296 & 144 & 60 & 539 & 257 & 108 & 742 & 355 & 146 & 821 & 478 & 232 & 495 & 292 & 153 \\
\hline Congo DR & 2304 & 1400 & 683 & 4176 & 2502 & 1226 & 5543 & 3606 & 1959 & 5508 & 4276 & 2987 & 3302 & 2486 & 1718 \\
\hline Denmark & 233 & 94 & 34 & 425 & 167 & 61 & 594 & 224 & 73 & 680 & 318 & 107 & 387 & 183 & 69 \\
\hline Dominican Rep. & 3586 & 2600 & 1577 & 6485 & 4658 & 2832 & 8321 & 6304 & 4295 & 7672 & 6423 & 5075 & 4633 & 3793 & 2953 \\
\hline East Timor & 4103 & 3117 & 2094 & 7415 & 5589 & 3763 & 10034 & 8017 & 6008 & 8395 & 7145 & 5798 & 5046 & 4206 & 3366 \\
\hline Ecuador & 1244 & 609 & 224 & 2262 & 1084 & 401 & 3250 & 1656 & 651 & 3685 & 2467 & 1363 & 2129 & 1386 & 825 \\
\hline
\end{tabular}




\begin{tabular}{|c|c|c|c|c|c|c|c|c|c|c|c|c|c|c|c|}
\hline $\begin{array}{c}\text { CDD } \\
\text { Average 1964-2013 }\end{array}$ & $\begin{array}{l}\text { Temp } \\
15.6^{\circ} \mathrm{C}\end{array}$ & $\begin{array}{l}\text { Temp } \\
18.3^{\circ} \mathrm{C}\end{array}$ & $\begin{array}{l}\text { Temp } \\
21.1^{\circ} \mathrm{C}\end{array}$ & $\begin{array}{l}\text { Temp } \\
60^{\circ} \mathrm{F}\end{array}$ & $\begin{array}{r}\text { Temp } \\
65^{\circ} \mathrm{F}\end{array}$ & $\begin{array}{l}\text { Temp } \\
70^{\circ} \mathrm{F}\end{array}$ & $\begin{array}{c}\text { Heat } \\
\text { Index } \\
57.56^{\circ} \mathrm{F}\end{array}$ & $\begin{array}{l}\text { Heat } \\
\text { Index } \\
63.08^{\circ} \mathrm{F}\end{array}$ & $\begin{array}{c}\text { Heat } \\
\text { Index } \\
68.58^{\circ} \mathrm{F}\end{array}$ & $\begin{array}{l}\text { Humidex } \\
13.98^{\circ} \mathrm{C}\end{array}$ & $\begin{array}{l}\text { Humidex } \\
17.4^{\circ} \mathrm{C}\end{array}$ & $\begin{array}{l}\text { Humidex } \\
21.09^{\circ} \mathrm{C}\end{array}$ & $\begin{array}{c}\text { ESI } \\
12.6^{\circ} \mathrm{C}\end{array}$ & $\begin{array}{c}\mathrm{ESI} \\
14.9^{\circ} \mathrm{C}\end{array}$ & $\begin{array}{c}\text { ESI } \\
17.2^{\circ} \mathrm{C}\end{array}$ \\
\hline Egypt & 2387 & 1725 & 1166 & 4318 & 3092 & 2095 & 4683 & 3274 & 2129 & 3449 & 2514 & 1670 & 2134 & 1534 & 1030 \\
\hline El Salvador & 2638 & 1662 & 788 & 4778 & 2971 & 1413 & 6107 & 4097 & 2183 & 5961 & 4712 & 3368 & 3583 & 2744 & 1915 \\
\hline Equatorial Guinea & 2479 & 1496 & 623 & 4491 & 2672 & 1117 & 6004 & 3988 & 2038 & 6263 & 5014 & 3667 & 3774 & 2934 & 2094 \\
\hline Eritrea & 3622 & 2688 & 1820 & 6549 & 4818 & 3270 & 7834 & 5887 & 4118 & 5989 & 4758 & 3492 & 3610 & 2799 & 2041 \\
\hline Estonia & 268 & 134 & 57 & 488 & 239 & 103 & 625 & 298 & 122 & 613 & 332 & 144 & 371 & 203 & 96 \\
\hline Ethiopia & 1562 & 961 & 551 & 2832 & 1718 & 989 & 3450 & 2049 & 1102 & 3130 & 2059 & 1163 & 1868 & 1225 & 735 \\
\hline Finland & 190 & 88 & 35 & 345 & 157 & 62 & 456 & 200 & 75 & 473 & 241 & 96 & 283 & 146 & 64 \\
\hline France & 427 & 232 & 115 & 775 & 415 & 206 & 1002 & 523 & 248 & 1011 & 594 & 296 & 610 & 365 & 196 \\
\hline Gabon & 3000 & 2017 & 1081 & 5429 & 3608 & 1940 & 7120 & 5105 & 3134 & 6860 & 5611 & 4263 & 4130 & 3290 & 2451 \\
\hline Gambia & 3759 & 2783 & 1801 & 6795 & 4988 & 3235 & 8365 & 6367 & 4418 & 6736 & 5497 & 4182 & 4090 & 3262 & 2452 \\
\hline Georgia & 216 & 104 & 47 & 394 & 186 & 84 & 554 & 254 & 106 & 648 & 357 & 163 & 392 & 226 & 115 \\
\hline Germany & 304 & 155 & 70 & 553 & 277 & 126 & 737 & 363 & 159 & 784 & 447 & 215 & 473 & 276 & 143 \\
\hline Ghana & 3656 & 2687 & 1707 & 6609 & 4816 & 3065 & 8603 & 6616 & 4667 & 7668 & 6432 & 5112 & 4578 & 3752 & 2935 \\
\hline Greece & 1116 & 753 & 476 & 2021 & 1348 & 856 & 2301 & 1489 & 896 & 1860 & 1261 & 758 & 1130 & 763 & 474 \\
\hline Guatemala & 2755 & 1788 & 888 & 4988 & 3197 & 1593 & 6330 & 4329 & 2425 & 6163 & 4915 & 3576 & 3710 & 2874 & 2051 \\
\hline Guinea & 3577 & 2643 & 1744 & 6468 & 4737 & 3133 & 7723 & 5797 & 3963 & 6532 & 5326 & 4064 & 3944 & 3145 & 2372 \\
\hline Guinea-Bissau & 4141 & 3176 & 2222 & 7483 & 5696 & 3993 & 8745 & 6760 & 4864 & 6812 & 5572 & 4274 & 4116 & 3293 & 2506 \\
\hline Haiti & 3806 & 2820 & 1798 & 6881 & 5055 & 3228 & 8983 & 6966 & 4957 & 7949 & 6700 & 5352 & 4790 & 3949 & 3109 \\
\hline Honduras & 2687 & 1709 & 816 & 4866 & 3055 & 1463 & 6244 & 4232 & 2299 & 6134 & 4884 & 3538 & 3689 & 2849 & 2017 \\
\hline Hungary & 507 & 274 & 132 & 920 & 490 & 237 & 1241 & 670 & 319 & 1315 & 846 & 470 & 787 & 506 & 295 \\
\hline India & 3519 & 2700 & 1919 & 6359 & 4842 & 3450 & 7622 & 5917 & 4342 & 5874 & 4787 & 3685 & 3540 & 2829 & 2160 \\
\hline Indonesia & 3513 & 2527 & 1509 & 6353 & 4527 & 2709 & 8609 & 6593 & 4585 & 8043 & 6794 & 5446 & 4846 & 4006 & 3166 \\
\hline Iran & 1628 & 1231 & 894 & 2943 & 2208 & 1607 & 2944 & 2120 & 1457 & 1791 & 1261 & 813 & 1152 & 812 & 539 \\
\hline Iraq & 2870 & 2310 & 1803 & 5184 & 4147 & 3241 & 5123 & 3954 & 2946 & 3237 & 2477 & 1777 & 2004 & 1515 & 1097 \\
\hline Ireland & 57 & 11 & 2 & 105 & 19 & 4 & 206 & 33 & 5 & 385 & 109 & 15 & 193 & 57 & 11 \\
\hline Italy & 617 & 352 & 172 & 1120 & 629 & 309 & 1475 & 839 & 421 & 1525 & 997 & 583 & 907 & 594 & 358 \\
\hline Japan & 994 & 588 & 276 & 1804 & 1050 & 495 & 2475 & 1555 & 851 & 2609 & 1942 & 1334 & 1548 & 1130 & 775 \\
\hline Jordan & 1757 & 1249 & 833 & 3179 & 2239 & 1497 & 3472 & 2376 & 1522 & 2561 & 1817 & 1164 & 1600 & 1128 & 744 \\
\hline Kazakhstan & 710 & 481 & 303 & 1285 & 861 & 545 & 1395 & 902 & 539 & 991 & 651 & 375 & 628 & 412 & 247 \\
\hline Kenya & 1680 & 951 & 519 & 3050 & 1699 & 932 & 3928 & 2231 & 1149 & 3732 & 2529 & 1423 & 2211 & 1465 & 854 \\
\hline Kuwait & 4021 & 3290 & 2614 & 7261 & 5907 & 4701 & 7183 & 5657 & 4308 & 4649 & 3662 & 2715 & 2847 & 2207 & 1636 \\
\hline Kyrgyz Rep. & 167 & 95 & 46 & 303 & 171 & 83 & 312 & 167 & 76 & 164 & 78 & 27 & 128 & 64 & 25 \\
\hline Lao PDR & 2454 & 1592 & 834 & 4444 & 2847 & 1496 & 5906 & 4069 & 2440 & 5817 & 4625 & 3401 & 3482 & 2701 & 1964 \\
\hline Latvia & 276 & 135 & 57 & 502 & 241 & 102 & 663 & 313 & 127 & 687 & 379 & 170 & 410 & 230 & 111 \\
\hline Lebanon & 1759 & 1197 & 733 & 3184 & 2144 & 1316 & 3791 & 2574 & 1591 & 3209 & 2359 & 1597 & 1953 & 1417 & 963 \\
\hline Lesotho & 797 & 473 & 263 & 1446 & 846 & 473 & 1665 & 917 & 470 & 1350 & 778 & 373 & 853 & 510 & 278 \\
\hline Liberia & 3451 & 2466 & 1456 & 6241 & 4418 & 2614 & 8205 & 6191 & 4190 & 7816 & 6567 & 5220 & 4712 & 3872 & 3033 \\
\hline
\end{tabular}




\begin{tabular}{|c|c|c|c|c|c|c|c|c|c|c|c|c|c|c|c|}
\hline $\begin{array}{c}\text { CDD } \\
\text { Average 1964-2013 }\end{array}$ & emp & $\begin{array}{l}\text { Temp } \\
18.3^{\circ} \mathrm{C}\end{array}$ & $\begin{array}{l}\text { Temp } \\
21.1^{\circ} \mathrm{C}\end{array}$ & $\begin{array}{l}\text { Temp } \\
60^{\circ} \mathrm{F}\end{array}$ & $\begin{array}{l}\text { Temp } \\
65^{\circ} \mathrm{F}\end{array}$ & $\begin{array}{l}\text { Temp } \\
70^{\circ} \mathrm{F}\end{array}$ & $\begin{array}{c}\text { Heat } \\
\text { Index } \\
57.56^{\circ} \mathrm{F}\end{array}$ & $\begin{array}{l}\text { Heat } \\
\text { Index } \\
63.08^{\circ} \mathrm{F}\end{array}$ & $\begin{array}{c}\text { Heat } \\
\text { Index } \\
68.58^{\circ} \mathrm{F}\end{array}$ & $\begin{array}{l}\text { Humidex } \\
13.98^{\circ} \mathrm{C}\end{array}$ & $\begin{array}{l}\text { Humidex } \\
17.4^{\circ} \mathrm{C}\end{array}$ & $\begin{array}{l}\text { Humidex } \\
21.09^{\circ} \mathrm{C}\end{array}$ & $\begin{array}{l}\text { ESI } \\
12.6^{\circ} \mathrm{C}\end{array}$ & $\begin{array}{c}\text { ESI } \\
14.9^{\circ} \mathrm{C}\end{array}$ & $\begin{array}{c}\text { ESI } \\
17.2^{\circ} \mathrm{C}\end{array}$ \\
\hline Libya & 2330 & 1718 & 1208 & 4214 & 3080 & 2171 & 4445 & 3155 & 2115 & 3068 & 2226 & 1478 & 1901 & 1360 & 914 \\
\hline Lithuania & 290 & 142 & 60 & 527 & 253 & 108 & 701 & 333 & 136 & 735 & 413 & 190 & 439 & 250 & 123 \\
\hline Macedonia & 763 & 488 & 292 & 1384 & 873 & 525 & 1596 & 965 & 543 & 1309 & 825 & 445 & 802 & 511 & 296 \\
\hline Madagascar & 2024 & 1195 & 553 & 3669 & 2135 & 991 & 4735 & 2920 & 1454 & 4696 & 3481 & 2277 & 2824 & 2042 & 1341 \\
\hline Malawi & 2372 & 1564 & 927 & 4295 & 2799 & 1664 & 5101 & 3364 & 1950 & 4380 & 3232 & 2122 & 2658 & 1921 & 1272 \\
\hline Malaysia & 3206 & 2220 & 1212 & 5800 & 3973 & 2175 & 7826 & 5810 & 3804 & 7680 & 6431 & 5083 & 4630 & 3789 & 2949 \\
\hline Mali & 4104 & 3221 & 2370 & 7414 & 5778 & 4261 & 8226 & 6420 & 4735 & 5937 & 4830 & 3707 & 3602 & 2878 & 2195 \\
\hline Mauritania & 4520 & 3642 & 2807 & 8162 & 6537 & 5048 & 8409 & 6612 & 4975 & 5405 & 4299 & 3214 & 3304 & 2586 & 1935 \\
\hline Mexico & 1607 & 986 & 529 & 2913 & 1763 & 950 & 3721 & 2296 & 1252 & 3565 & 2539 & 1606 & 2141 & 1509 & 982 \\
\hline Moldova & 586 & 325 & 157 & 1065 & 580 & 282 & 1371 & 754 & 359 & 1343 & 868 & 477 & 805 & 517 & 296 \\
\hline Mongolia & 443 & 284 & 167 & 803 & 509 & 301 & 847 & 513 & 282 & 532 & 309 & 148 & 357 & 212 & 110 \\
\hline Montenegro & 608 & 365 & 203 & 1103 & 653 & 364 & 1319 & 748 & 389 & 1154 & 698 & 352 & 705 & 431 & 235 \\
\hline Morocco & 1688 & 1222 & 847 & 3055 & 2190 & 1522 & 3204 & 2200 & 1442 & 2209 & 1511 & 942 & 1389 & 952 & 614 \\
\hline Mozambique & 2754 & 1888 & 1129 & 4984 & 3381 & 2028 & 6110 & 4276 & 2660 & 5385 & 4196 & 2989 & 3257 & 2481 & 1757 \\
\hline Myanmar & 2884 & 2046 & 1272 & 5217 & 3665 & 2285 & 6586 & 4825 & 3219 & 5855 & 4724 & 3565 & 3513 & 2772 & 2071 \\
\hline Namibia & 2653 & 1978 & 1402 & 4797 & 3547 & 2520 & 4950 & 3540 & 2371 & 3257 & 2364 & 1535 & 2039 & 1462 & 973 \\
\hline Nepal & 1299 & 844 & 494 & 2354 & 1510 & 887 & 3023 & 2000 & 1232 & 2737 & 2014 & 1370 & 1667 & 1212 & 832 \\
\hline Netherlands & 195 & 74 & 27 & 357 & 132 & 48 & 524 & 184 & 60 & 642 & 291 & 95 & 367 & 170 & 64 \\
\hline New Zealand & 263 & 83 & 20 & 482 & 147 & 36 & 743 & 228 & 50 & 966 & 430 & 126 & 528 & 238 & 81 \\
\hline Nicaragua & 2747 & 1767 & 861 & 4975 & 3159 & 1545 & 6439 & 4425 & 2479 & 6354 & 5105 & 3758 & 3812 & 2973 & 2137 \\
\hline Niger & 4278 & 3429 & 2616 & 7727 & 6154 & 4703 & 8424 & 6691 & 5093 & 5725 & 4671 & 3614 & 3478 & 2792 & 2150 \\
\hline Nigeria & 3496 & 2577 & 1685 & 6320 & 4619 & 3028 & 7787 & 5900 & 4093 & 6628 & 5455 & 4225 & 3989 & 3213 & 2456 \\
\hline Norway & 30 & 9 & 2 & 54 & 16 & 4 & 84 & 24 & 5 & 124 & 43 & 11 & 71 & 27 & 8 \\
\hline Oman & 4212 & 3364 & 2570 & 7607 & 6036 & 4621 & 8210 & 6429 & 4823 & 5797 & 4641 & 3483 & 3499 & 2750 & 2057 \\
\hline Pakistan & 3013 & 2368 & 1781 & 5444 & 4248 & 3201 & 6385 & 5026 & 3838 & 4567 & 3676 & 2822 & 2742 & 2167 & 1652 \\
\hline Palestine & 1469 & 846 & 372 & 2666 & 1511 & 667 & 3475 & 2092 & 1052 & 3433 & 2432 & 1567 & 2069 & 1446 & 935 \\
\hline Panama & 3588 & 2602 & 1580 & 6488 & 4662 & 2836 & 8500 & 6484 & 4475 & 8098 & 6849 & 5501 & 4865 & 4025 & 3185 \\
\hline Papua New & 2480 & 1511 & 677 & 4494 & 2698 & 1213 & 5979 & 3967 & 2097 & 6138 & 4889 & 3543 & 3711 & 2871 & 2042 \\
\hline Paraguay & 2359 & 1563 & 877 & 4271 & 2798 & 1574 & 5727 & 4015 & 2534 & 5438 & 4306 & 3165 & 3253 & 2517 & 1835 \\
\hline Peru & 757 & 410 & 178 & 1375 & 732 & 320 & 1886 & 1063 & 511 & 2023 & 1335 & 791 & 1204 & 800 & 492 \\
\hline Philippines & 3939 & 2953 & 1930 & 7120 & 5294 & 3468 & 9731 & 7714 & 5705 & 8491 & 7242 & 5894 & 5097 & 4257 & 3417 \\
\hline Poland & 383 & 200 & 91 & 695 & 357 & 164 & 909 & 462 & 205 & 921 & 546 & 271 & 555 & 331 & 175 \\
\hline Portugal & 615 & 275 & 111 & 1119 & 490 & 199 & 1556 & 694 & 247 & 1762 & 998 & 444 & 1003 & 569 & 270 \\
\hline Congo & 2792 & 1810 & 874 & 5054 & 3236 & 1568 & 6736 & 4723 & 2752 & 6645 & 5396 & 4050 & 4005 & 3165 & 2328 \\
\hline Romania & 460 & 242 & 112 & 835 & 432 & 202 & 1112 & 577 & 260 & 1157 & 719 & 377 & 691 & 430 & 239 \\
\hline Russia & 410 & 233 & 120 & 745 & 417 & 215 & 940 & 520 & 256 & 902 & 568 & 305 & 543 & 341 & 192 \\
\hline Rwanda & 1117 & 447 & 159 & 2036 & 795 & 284 & 3010 & 1282 & 448 & 3409 & 2175 & 1016 & 1975 & 1210 & 611 \\
\hline
\end{tabular}




\begin{tabular}{|c|c|c|c|c|c|c|c|c|c|c|c|c|c|c|c|}
\hline $\begin{array}{c}\text { CDD } \\
\text { Average 1964-2013 }\end{array}$ & $\begin{array}{r}\text { Temp } \\
15.6^{\circ} \mathrm{C}\end{array}$ & $\begin{array}{l}\text { Temp } \\
18.3^{\circ} \mathrm{C}\end{array}$ & $\begin{array}{l}\text { Temp } \\
21.1^{\circ} \mathrm{C}\end{array}$ & $\begin{array}{l}\text { Temp } \\
60^{\circ} \mathrm{F}\end{array}$ & $\begin{array}{l}\text { Temp } \\
65^{\circ} \mathrm{F}\end{array}$ & $\begin{array}{l}\text { Temp } \\
70^{\circ} \mathrm{F}\end{array}$ & $\begin{array}{c}\text { Heat } \\
\text { Index } \\
57.56^{\circ} \mathrm{F}\end{array}$ & $\begin{array}{l}\text { Heat } \\
\text { Index } \\
63.08^{\circ} \mathrm{F}\end{array}$ & $\begin{array}{l}\text { Heat } \\
\text { Index } \\
68.58^{\circ} \mathrm{F}\end{array}$ & $\begin{array}{l}\text { Humidex } \\
13.98^{\circ} \mathrm{C}\end{array}$ & $\begin{array}{l}\text { Humidex } \\
17.4^{\circ} \mathrm{C}\end{array}$ & $\begin{array}{l}\text { Humidex } \\
21.09^{\circ} \mathrm{C}\end{array}$ & $\begin{array}{c}\mathrm{ESI} \\
12.6^{\circ} \mathrm{C}\end{array}$ & $\begin{array}{c}\text { ESI } \\
14.9^{\circ} \mathrm{C}\end{array}$ & $\begin{array}{c}\text { ESI } \\
17.2^{\circ} \mathrm{C}\end{array}$ \\
\hline Saudi Arabia & 3669 & 2908 & 2213 & 6627 & 5219 & 3979 & 6632 & 5059 & 3684 & 4149 & 3158 & 2225 & 2574 & 1935 & 1381 \\
\hline Senegal & 4037 & 3081 & 2127 & 7296 & 5526 & 3822 & 8672 & 6716 & 4829 & 6700 & 5491 & 4225 & 4068 & 3264 & 2487 \\
\hline Serbia & 519 & 302 & 163 & 942 & 540 & 292 & 1181 & 656 & 335 & 1129 & 696 & 367 & 683 & 427 & 241 \\
\hline Sierra Leone & 3821 & 2840 & 1838 & 6906 & 5090 & 3301 & 9004 & 6995 & 5008 & 7932 & 6685 & 5342 & 4765 & 3927 & 3093 \\
\hline Slovakia & 405 & 212 & 97 & 736 & 378 & 174 & 976 & 501 & 223 & 1014 & 617 & 316 & 612 & 374 & 204 \\
\hline Slovenia & 272 & 128 & 51 & 495 & 228 & 91 & 704 & 325 & 129 & 820 & 471 & 224 & 493 & 289 & 151 \\
\hline Somalia & 4146 & 3169 & 2182 & 7493 & 5683 & 3921 & 8685 & 6681 & 4719 & 6809 & 5562 & 4227 & 4107 & 3272 & 2447 \\
\hline South Africa & 1198 & 701 & 372 & 2174 & 1252 & 667 & 2643 & 1504 & 749 & 2362 & 1538 & 850 & 1437 & 928 & 538 \\
\hline South Korea & 832 & 475 & 206 & 1509 & 849 & 369 & 2050 & 1249 & 640 & 2182 & 1602 & 1080 & 1305 & 940 & 632 \\
\hline South Sudan & 3476 & 2501 & 1561 & 6285 & 4480 & 2804 & 7616 & 5618 & 3693 & 6490 & 5253 & 3942 & 3905 & 3079 & 2271 \\
\hline Spain & 868 & 589 & 383 & 1573 & 1055 & 687 & 1771 & 1135 & 698 & 1414 & 923 & 544 & 879 & 580 & 359 \\
\hline Sri-Lanka & 3745 & 2759 & 1738 & 6771 & 4944 & 3121 & 8761 & 6745 & 4737 & 8017 & 6768 & 5420 & 4827 & 3987 & 3147 \\
\hline Sudan & 4241 & 3313 & 2411 & 7661 & 5943 & 4334 & 8365 & 6468 & 4683 & 5927 & 4761 & 3574 & 3590 & 2819 & 2097 \\
\hline Swaziland & 1846 & 1155 & 618 & 3346 & 2065 & 1109 & 4191 & 2664 & 1451 & 3913 & 2854 & 1852 & 2361 & 1694 & 1112 \\
\hline Sweden & 179 & 76 & 29 & 326 & 136 & 52 & 447 & 178 & 63 & 501 & 238 & 85 & 292 & 142 & 57 \\
\hline Switzerland & 144 & 62 & 22 & 263 & 110 & 39 & 373 & 157 & 53 & 445 & 231 & 97 & 275 & 151 & 71 \\
\hline Syria & 1852 & 1350 & 922 & 3350 & 2420 & 1657 & 3750 & 2669 & 1787 & 2892 & 2145 & 1474 & 1770 & 1297 & 898 \\
\hline Tajikistan & 530 & 360 & 228 & 960 & 645 & 409 & 979 & 630 & 375 & 562 & 344 & 182 & 395 & 247 & 140 \\
\hline Tanzania & 1801 & 1011 & 523 & 3269 & 1806 & 938 & 4176 & 2381 & 1162 & 3955 & 2747 & 1580 & 2364 & 1593 & 946 \\
\hline Thailand & 3220 & 2277 & 1363 & 5825 & 4078 & 2447 & 7734 & 5775 & 3916 & 7092 & 5859 & 4554 & 4245 & 3424 & 2625 \\
\hline Togo & 3621 & 2663 & 1706 & 6546 & 4772 & 3065 & 8344 & 6374 & 4459 & 7347 & 6117 & 4810 & 4357 & 3538 & 2733 \\
\hline Tunisia & 1895 & 1323 & 863 & 3430 & 2369 & 1551 & 3922 & 2674 & 1710 & 3152 & 2270 & 1513 & 1911 & 1361 & 914 \\
\hline Turkey & 919 & 626 & 402 & 1664 & 1121 & 722 & 1836 & 1187 & 719 & 1392 & 916 & 532 & 870 & 576 & 352 \\
\hline Turkmenis & 1957 & 1520 & 1136 & 3537 & 2727 & 2041 & 3506 & 2599 & 1844 & 2141 & 1562 & 1053 & 1356 & 985 & 681 \\
\hline Uganda & 1470 & 603 & 187 & 2675 & 1069 & 334 & 3763 & 1819 & 526 & 4077 & 2829 & 1523 & 2418 & 1593 & 845 \\
\hline Ukraine & 588 & 340 & 174 & 1067 & 608 & 311 & 1330 & 756 & 377 & 1238 & 800 & 444 & 747 & 480 & 276 \\
\hline $\begin{array}{l}\text { United Aral } \\
\text { Emirates }\end{array}$ & 4351 & 3519 & 2748 & 7858 & 6317 & 4940 & 8252 & 6504 & 4942 & 5668 & 4530 & 3401 & 3429 & 2692 & 2019 \\
\hline United Kingdom & & 69 & 20 & 323 & 122 & 35 & 438 & 159 & 46 & 499 & & 62 & 293 & 131 & 47 \\
\hline United States & 1120 & 729 & 418 & 2029 & 1304 & 751 & 2603 & 1737 & 1058 & 2394 & 1785 & 1229 & 1452 & 1065 & 736 \\
\hline Uruguay & 1341 & 808 & 422 & 2432 & 1444 & 758 & 3182 & 1965 & 1078 & 3110 & 2219 & 1424 & 1856 & 1303 & 846 \\
\hline Uzbekistan & 1459 & 1115 & 822 & 2637 & 2001 & 1478 & 2602 & 1889 & 1316 & 1556 & 1100 & 719 & 1011 & 718 & 485 \\
\hline Venezuela & 3263 & 2279 & 1311 & 5902 & 4080 & 2353 & 7559 & 5543 & 3563 & 6951 & 5701 & 4354 & 4193 & 3353 & 2513 \\
\hline Vietnam & 2827 & 1956 & 1151 & 5115 & 3503 & 2066 & 6946 & 5108 & 3430 & 6464 & 5278 & 4052 & 3866 & 3084 & 2339 \\
\hline Yemen & 3647 & 2776 & 1983 & 6592 & 4978 & 3565 & 7192 & 5356 & 3743 & 5226 & 4037 & 2852 & 3161 & 2390 & 1689 \\
\hline Zambia & 2034 & 1293 & 765 & 3686 & 2313 & 1373 & 4335 & 2712 & 1496 & 3648 & 2583 & 1571 & 2227 & 1542 & 961 \\
\hline Zimbabwe & 2048 & 1367 & 842 & 3708 & 2447 & 1513 & 4276 & 2807 & 1643 & 3481 & 2508 & 1588 & 2141 & 1518 & 979 \\
\hline
\end{tabular}




\begin{tabular}{|c|c|c|c|c|c|c|c|c|c|c|c|c|c|c|c|}
\hline $\begin{array}{c}\text { HDD } \\
\text { Average 1964-2013 }\end{array}$ & $\begin{array}{l}\text { Temp } \\
15.6^{\circ} \mathrm{C}\end{array}$ & $\begin{array}{l}\text { Temp } \\
18.3^{\circ} \mathrm{C}\end{array}$ & $\begin{array}{l}\text { Temp } \\
21.1^{\circ} \mathrm{C}\end{array}$ & $\begin{array}{l}\text { Temp } \\
60^{\circ} \mathrm{F}\end{array}$ & $\begin{array}{l}\text { Temp } \\
65^{\circ} \mathrm{F}\end{array}$ & $\begin{array}{l}\text { Temp } \\
70^{\circ} \mathrm{F}\end{array}$ & $\begin{array}{c}\text { Heat } \\
\text { Index } \\
57.56^{\circ} \mathrm{F}\end{array}$ & $\begin{array}{l}\text { Heat } \\
\text { Index } \\
63.08^{\circ} \mathrm{F}\end{array}$ & $\begin{array}{l}\text { Heat } \\
\text { Index } \\
68.58^{\circ} \mathrm{F}\end{array}$ & $\begin{array}{l}\text { Humidex } \\
13.98^{\circ} \mathrm{C}\end{array}$ & $\begin{array}{l}\text { Humidex } \\
17.4^{\circ} \mathrm{C}\end{array}$ & $\begin{array}{l}\text { Humidex } \\
21.09^{\circ} \mathrm{C}\end{array}$ & $\begin{array}{c}\text { ESI } \\
12.6^{\circ} \mathrm{C}\end{array}$ & $\begin{array}{c}\text { ESI } \\
14.9^{\circ} \mathrm{C}\end{array}$ & $\begin{array}{l}\text { ESI } \\
17.2^{\circ} \mathrm{C}\end{array}$ \\
\hline Albania & 1747 & 2413 & 3216 & 3127 & 4359 & 5796 & 2787 & 4069 & 5582 & 1479 & 2171 & 3061 & 1517 & 2018 & 2596 \\
\hline Algeria & 1186 & 1714 & 2360 & 2120 & 3097 & 4254 & 1937 & 2979 & 4232 & 1036 & 1629 & 2425 & 1061 & 1483 & 1995 \\
\hline Angola & 184 & 369 & 750 & 328 & 670 & 1354 & 293 & 575 & 1158 & 151 & 272 & 488 & 154 & 257 & 436 \\
\hline Argentina & 1162 & 1670 & 2329 & 2078 & 3018 & 4198 & 1870 & 2828 & 4044 & 1025 & 1529 & 2222 & 1010 & 1381 & 1837 \\
\hline Armenia & 4068 & 4928 & 5871 & 7298 & 8890 & 10574 & 6689 & 8396 & 10227 & 4033 & 5000 & 6163 & 3941 & 4615 & 5346 \\
\hline Australia & 650 & 1154 & 1839 & 1157 & 2090 & 3317 & 976 & 1907 & 3169 & 413 & 866 & 1562 & 480 & 829 & 1293 \\
\hline Austria & 3775 & 4640 & 5600 & 6771 & 8371 & 10086 & 6169 & 7865 & 9710 & 3694 & 4641 & 5782 & 3631 & 4295 & 5018 \\
\hline Azerbaijan & 3206 & 3970 & 4836 & 5749 & 7163 & 8711 & 5240 & 6742 & 8410 & 3117 & 3958 & 4991 & 3066 & 3660 & 4318 \\
\hline Bangladesh & 113 & 217 & 383 & 202 & 394 & 691 & 154 & 331 & 611 & 55 & 126 & 255 & 87 & 157 & 257 \\
\hline Belarus & 3937 & 4748 & 5668 & 7064 & 8565 & 10210 & 6498 & 8083 & 9844 & 3951 & 4840 & 5918 & 3904 & 4529 & 5217 \\
\hline Belgium & 2346 & 3140 & 4045 & 4201 & 5671 & 7288 & 3734 & 5274 & 7013 & 2037 & 2866 & 3920 & 2104 & 2700 & 3373 \\
\hline Benin & 25 & 72 & 163 & 45 & 132 & 294 & 42 & 128 & 281 & 27 & 76 & 164 & 36 & 83 & 150 \\
\hline Bolivia & 1716 & 2340 & 3102 & 3071 & 4228 & 5589 & 2736 & 3937 & 5353 & 1515 & 2164 & 2998 & 1463 & 1916 & 2446 \\
\hline Bosnia-Herzegovina & 2189 & 2903 & 3747 & 3921 & 5243 & 6751 & 3510 & 4882 & 6478 & 1960 & 2699 & 3639 & 1986 & 2518 & 3127 \\
\hline Botswana & 626 & 948 & 1435 & 1118 & 1716 & 2587 & 1037 & 1647 & 2509 & 577 & 915 & 1405 & 564 & 816 & 1147 \\
\hline Brazil & 88 & 216 & 497 & 156 & 392 & 898 & 108 & 287 & 691 & 38 & 88 & 211 & 54 & 110 & 217 \\
\hline Bulgaria & 2400 & 3088 & 3901 & 4302 & 5574 & 7028 & 3889 & 5217 & 6756 & 2252 & 2981 & 3897 & 2243 & 2766 & 3360 \\
\hline Burkina Faso & 53 & 140 & 292 & 93 & 255 & 527 & 105 & 284 & 572 & 84 & 206 & 399 & 94 & 198 & 334 \\
\hline Burundi & 38 & 374 & 1108 & 65 & 686 & 2000 & 15 & 343 & 1556 & 2 & 25 & 260 & 10 & 100 & 369 \\
\hline Cambodia & 3 & 16 & 66 & 5 & 29 & 120 & 2 & 15 & 74 & 0 & 2 & 10 & 1 & 4 & 15 \\
\hline Cameroon & 25 & 71 & 321 & 45 & 129 & 581 & 44 & 108 & 341 & 27 & 60 & 117 & 27 & 56 & 101 \\
\hline Canada & 4524 & 5357 & 6281 & 8120 & 9663 & 11312 & 7537 & 9191 & 10971 & 4616 & 5576 & 6701 & 4501 & 5164 & 5874 \\
\hline Central African Rep. & 12 & 37 & 179 & 20 & 67 & 324 & 19 & 60 & 180 & 11 & 31 & 71 & 13 & 31 & 63 \\
\hline Chad & 50 & 118 & 251 & 89 & 214 & 453 & 99 & 238 & 477 & 72 & 168 & 334 & 68 & 148 & 266 \\
\hline Chile & 2588 & 3412 & 4322 & 4634 & 6161 & 7787 & 4236 & 5904 & 7692 & 2375 & 3371 & 4563 & 2340 & 3014 & 3745 \\
\hline China & 2183 & 2724 & 3387 & 3914 & 4916 & 6102 & 3619 & 4657 & 5882 & 2199 & 2774 & 3491 & 2065 & 2474 & 2939 \\
\hline Colombia & 35 & 262 & 797 & 60 & 480 & 1440 & 11 & 215 & 969 & 0 & 8 & 113 & 3 & 41 & 198 \\
\hline Costa Rica & 0 & 0 & 1 & 0 & 0 & 1 & 0 & 0 & 0 & 0 & 0 & 0 & 0 & 0 & 0 \\
\hline Cote d'Ivoire & 6 & 21 & 69 & 11 & 38 & 125 & 9 & 32 & 85 & 5 & 14 & 34 & 7 & 17 & 34 \\
\hline Croatia & 2365 & 3095 & 3952 & 4236 & 5589 & 7121 & 3787 & 5187 & 6807 & 2140 & 2892 & 3841 & 2171 & 2712 & 3327 \\
\hline Cuba & 0 & 0 & 3 & 0 & 0 & 5 & 0 & 0 & 2 & 0 & 0 & 0 & 0 & 0 & 0 \\
\hline Czech Rep. & 3503 & 4337 & 5276 & 6281 & 7826 & 9503 & 5723 & 7352 & 9152 & 3416 & 4322 & 5424 & 3363 & 4001 & 4701 \\
\hline Congo DR & 17 & 99 & 404 & 29 & 181 & 731 & 19 & 98 & 459 & 7 & 24 & 83 & 10 & 35 & 107 \\
\hline Denmark & 2435 & 3282 & 4245 & 4360 & 5928 & 7648 & 3910 & 5555 & 7414 & 2170 & 3057 & 4193 & 2180 & 2816 & 3542 \\
\hline Dominican Rep. & 0 & 0 & 0 & 0 & 0 & 0 & 0 & 0 & 0 & 0 & 0 & 0 & 0 & 0 & 0 \\
\hline East Timor & 0 & 0 & 0 & 0 & 0 & 0 & 0 & 0 & 0 & 0 & 0 & 0 & 0 & 0 & 0 \\
\hline Ecuador & 94 & 445 & 1083 & 163 & 811 & 1955 & 44 & 466 & 1471 & 2 & 34 & 277 & 13 & 111 & 389 \\
\hline
\end{tabular}




\begin{tabular}{|c|c|c|c|c|c|c|c|c|c|c|c|c|c|c|c|}
\hline $\begin{array}{c}\text { HDD } \\
\text { Average 1964-2013 }\end{array}$ & $\begin{array}{l}\text { Temp } \\
15.6^{\circ} \mathrm{C}\end{array}$ & $\begin{array}{l}\text { Temp } \\
18.3^{\circ} \mathrm{C}\end{array}$ & $\begin{array}{l}\text { Temp } \\
21.1^{\circ} \mathrm{C}\end{array}$ & $\begin{array}{l}\text { Temp } \\
60^{\circ} \mathrm{F}\end{array}$ & $\begin{array}{l}\text { Temp } \\
65^{\circ} \mathrm{F}\end{array}$ & $\begin{array}{l}\text { Temp } \\
70^{\circ} \mathrm{F}\end{array}$ & $\begin{array}{l}\text { Heat } \\
\text { Index } \\
57.56^{\circ} \mathrm{F}\end{array}$ & $\begin{array}{c}\text { Heat } \\
\text { Index } \\
63.08^{\circ} \mathrm{F}\end{array}$ & $\begin{array}{c}\text { Heat } \\
\text { Index } \\
68.58^{\circ} \mathrm{F}\end{array}$ & $\begin{array}{l}\text { Humidex } \\
13.98^{\circ} \mathrm{C}\end{array}$ & $\begin{array}{l}\text { Humidex } \\
17.4^{\circ} \mathrm{C}\end{array}$ & $\begin{array}{l}\text { Humidex } \\
21.09^{\circ} \mathrm{C}\end{array}$ & $\begin{array}{c}\text { ESI } \\
12.6^{\circ} \mathrm{C}\end{array}$ & $\begin{array}{c}\text { ESI } \\
14.9^{\circ} \mathrm{C}\end{array}$ & $\begin{array}{c}\text { ESI } \\
17.2^{\circ} \mathrm{C}\end{array}$ \\
\hline Egypt & 531 & 855 & 1318 & 948 & 1548 & 2377 & 861 & 1468 & 2332 & 459 & 773 & 1277 & 465 & 705 & 1041 \\
\hline El Salvador & 1 & 11 & 159 & 1 & 21 & 289 & 0 & 6 & 101 & 0 & 0 & 4 & 0 & 1 & 12 \\
\hline Equatorial Guinea & 0 & 4 & 153 & 0 & 7 & 279 & 0 & 1 & 60 & 0 & 0 & 0 & 0 & 0 & 1 \\
\hline Eritrea & 12 & 64 & 219 & 22 & 117 & 396 & 13 & 82 & 322 & 3 & 22 & 104 & 9 & 38 & 120 \\
\hline Estonia & 4191 & 5042 & 5988 & 7519 & 9096 & 10786 & 6932 & 8621 & 10454 & 4234 & 5201 & 6362 & 4155 & 4827 & 5560 \\
\hline Ethiopia & 239 & 624 & 1236 & 421 & 1134 & 2230 & 266 & 880 & 1943 & 77 & 256 & 707 & 136 & 333 & 683 \\
\hline Finland & 4735 & 5619 & 6588 & 8497 & 10135 & 11866 & 7869 & 9630 & 11514 & 4833 & 5851 & 7054 & 4746 & 5450 & 6207 \\
\hline France & 2407 & 3199 & 4104 & 4311 & 5777 & 7394 & 3841 & 5378 & 7112 & 2110 & 2943 & 3992 & 2165 & 2761 & 3431 \\
\hline Gabon & 0 & 3 & 90 & 0 & 6 & 164 & 0 & 1 & 40 & 0 & 0 & 0 & 0 & 0 & 1 \\
\hline Gambia & 3 & 14 & 55 & 6 & 26 & 99 & 5 & 23 & 83 & 2 & 12 & 45 & 4 & 17 & 46 \\
\hline Georgia & 4078 & 4953 & 5918 & 7316 & 8935 & 10659 & 6682 & 8399 & 10259 & 4030 & 4988 & 6142 & 3955 & 4628 & 5358 \\
\hline Germany & 3156 & 3994 & 4931 & 5658 & 7209 & 8883 & 5113 & 6755 & 8560 & 2974 & 3886 & 5002 & 2970 & 3612 & 4320 \\
\hline Ghana & 8 & 26 & 68 & 14 & 47 & 122 & 11 & 40 & 100 & 6 & 19 & 47 & 9 & 23 & 46 \\
\hline Greece & 1729 & 2352 & 3099 & 3095 & 4249 & 5583 & 2757 & 3961 & 5378 & 1498 & 2147 & 2992 & 1535 & 2007 & 2559 \\
\hline Guatemala & 3 & 22 & 145 & 6 & 40 & 263 & 2 & 17 & 123 & 0 & 2 & 11 & 1 & 5 & 22 \\
\hline Guinea & 31 & 83 & 206 & 55 & 150 & 372 & 48 & 137 & 312 & 25 & 68 & 154 & 32 & 73 & 140 \\
\hline Guinea-Bissau & 6 & 27 & 95 & 10 & 49 & 172 & 6 & 36 & 150 & 1 & 10 & 59 & 4 & 21 & 74 \\
\hline Haiti & 0 & 0 & 0 & 0 & 0 & 0 & 0 & 0 & 0 & 0 & 0 & 0 & 0 & 0 & 0 \\
\hline Honduras & 0 & 8 & 138 & 0 & 16 & 250 & 0 & 4 & 80 & 0 & 0 & 2 & 0 & 1 & 8 \\
\hline Hungary & 2918 & 3672 & 4552 & 5231 & 6627 & 8200 & 4729 & 6174 & 7833 & 2785 & 3565 & 4537 & 2789 & 3348 & 3977 \\
\hline India & 304 & 471 & 713 & 543 & 852 & 1286 & 492 & 804 & 1237 & 263 & 425 & 671 & 281 & 410 & 581 \\
\hline Indonesia & 0 & 0 & 5 & 0 & 0 & 8 & 0 & 0 & 1 & 0 & 0 & 0 & 0 & 0 & 0 \\
\hline Iran & 2288 & 2878 & 3563 & 4102 & 5194 & 6419 & 3833 & 5025 & 6370 & 2362 & 3081 & 3981 & 2194 & 2694 & 3261 \\
\hline Iraq & 1230 & 1656 & 2171 & 2203 & 2992 & 3913 & 2024 & 2870 & 3872 & 1160 & 1649 & 2297 & 1132 & 1483 & 1905 \\
\hline Ireland & 2042 & 2982 & 3996 & 3649 & 5389 & 7200 & 3191 & 5033 & 7015 & 1510 & 2483 & 3737 & 1627 & 2331 & 3125 \\
\hline Italy & 2101 & 2822 & 3665 & 3762 & 5098 & 6604 & 3333 & 4713 & 6304 & 1838 & 2560 & 3493 & 1877 & 2404 & 3008 \\
\hline Japan & 1653 & 2233 & 2944 & 2960 & 4033 & 5305 & 2655 & 3751 & 5056 & 1499 & 2081 & 2821 & 1451 & 1873 & 2358 \\
\hline Jordan & 999 & 1478 & 2085 & 1786 & 2673 & 3757 & 1620 & 2540 & 3695 & 854 & 1359 & 2054 & 871 & 1238 & 1695 \\
\hline Kazakhstan & 4832 & 5589 & 6434 & 8675 & 10078 & 11588 & 8167 & 9690 & 11336 & 5113 & 6022 & 7094 & 4894 & 5519 & 6193 \\
\hline Kenya & 68 & 325 & 916 & 119 & 594 & 1654 & 45 & 364 & 1291 & 3 & 49 & 291 & 24 & 118 & 347 \\
\hline Kuwait & 434 & 690 & 1037 & 776 & 1248 & 1869 & 698 & 1189 & 1849 & 350 & 611 & 1012 & 371 & 571 & 840 \\
\hline Kyrgyz Rep. & 6801 & 7715 & 8689 & 12214 & 13908 & 15647 & 11571 & 13442 & 15360 & 7381 & 8544 & 9841 & 6662 & 7438 & 8239 \\
\hline Lao PDR & 94 & 218 & 483 & 167 & 396 & 872 & 120 & 300 & 680 & 44 & 100 & 224 & 63 & 121 & 225 \\
\hline Latvia & 3960 & 4806 & 5750 & 7105 & 8670 & 10358 & 6524 & 8190 & 10014 & 3956 & 4898 & 6036 & 3898 & 4558 & 5279 \\
\hline Lebanon & 659 & 1083 & 1641 & 1175 & 1960 & 2959 & 985 & 1784 & 2809 & 408 & 808 & 1393 & 495 & 799 & 1185 \\
\hline Lesotho & 1743 & 2406 & 3219 & 3120 & 4346 & 5800 & 2843 & 4111 & 5673 & 1684 & 2361 & 3304 & 1570 & 2067 & 2674 \\
\hline Liberia & 0 & 2 & 15 & 1 & 4 & 27 & 0 & 2 & 10 & 0 & 0 & 1 & 0 & 1 & 2 \\
\hline
\end{tabular}




\begin{tabular}{|c|c|c|c|c|c|c|c|c|c|c|c|c|c|c|c|}
\hline $\begin{array}{c}\text { HDD } \\
\text { Average 1964-2013 }\end{array}$ & $\begin{array}{l}\text { Temp } \\
15.6^{\circ} \mathrm{C}\end{array}$ & $\begin{array}{l}\text { Temp } \\
18.3^{\circ} \mathrm{C}\end{array}$ & $\begin{array}{l}\text { Temp } \\
21.1^{\circ} \mathrm{C}\end{array}$ & $\begin{array}{l}\text { Temp } \\
60^{\circ} \mathrm{F}\end{array}$ & $\begin{array}{l}\text { Temp } \\
65^{\circ} \mathrm{F}\end{array}$ & $\begin{array}{l}\text { Temp } \\
70^{\circ} \mathrm{F}\end{array}$ & $\begin{array}{c}\text { Heat } \\
\text { Index } \\
57.56^{\circ} \mathrm{F}\end{array}$ & $\begin{array}{c}\text { Heat } \\
\text { Index } \\
63.08^{\circ} \mathrm{F}\end{array}$ & $\begin{array}{l}\text { Heat } \\
\text { Index } \\
68.58^{\circ} \mathrm{F}\end{array}$ & $\begin{array}{l}\text { Humidex } \\
13.98^{\circ} \mathrm{C}\end{array}$ & $\begin{array}{l}\text { Humidex } \\
17.4^{\circ} \mathrm{C}\end{array}$ & $\begin{array}{l}\text { Humidex } \\
21.09^{\circ} \mathrm{C}\end{array}$ & $\begin{array}{c}\text { ESI } \\
12.6^{\circ} \mathrm{C}\end{array}$ & $\begin{array}{c}\text { ESI } \\
14.9^{\circ} \mathrm{C}\end{array}$ & $\begin{array}{c}\text { ESI } \\
17.2^{\circ} \mathrm{C}\end{array}$ \\
\hline Libya & 690 & 1064 & 1577 & 1233 & 1925 & 2843 & 1129 & 1855 & 2825 & 605 & 1012 & 1612 & 620 & 920 & 1314 \\
\hline Lithuania & 3805 & 4644 & 5584 & 6825 & 8378 & 10059 & 6254 & 7902 & 9714 & 3775 & 4702 & 5827 & 3726 & 4376 & 5090 \\
\hline Macedonia & 2336 & 3046 & 3873 & 4184 & 5500 & 6978 & 3767 & 5153 & 6740 & 2140 & 2905 & 3873 & 2147 & 2697 & 3322 \\
\hline Madagascar & 55 & 213 & 593 & 96 & 388 & 1071 & 44 & 246 & 788 & 5 & 39 & 183 & 21 & 79 & 219 \\
\hline Malawi & 106 & 284 & 669 & 186 & 517 & 1208 & 133 & 412 & 1007 & 40 & 140 & 378 & 69 & 172 & 362 \\
\hline Malaysia & 0 & 0 & 15 & 0 & 0 & 28 & 0 & 0 & 4 & 0 & 0 & 0 & 0 & 0 & 0 \\
\hline Mali & 81 & 184 & 356 & 143 & 333 & 642 & 158 & 369 & 693 & 114 & 256 & 480 & 120 & 236 & 393 \\
\hline Mauritania & 88 & 196 & 385 & 156 & 357 & 694 & 163 & 383 & 755 & 108 & 252 & 514 & 117 & 240 & 428 \\
\hline Mexico & 405 & 771 & 1337 & 721 & 1397 & 2410 & 572 & 1163 & 2128 & 256 & 480 & 895 & 309 & 518 & 831 \\
\hline Moldova & 2989 & 3714 & 4569 & 5361 & 6702 & 8231 & 4895 & 6294 & 7908 & 2934 & 3708 & 4665 & 2887 & 3438 & 4058 \\
\hline Mongolia & 6519 & 7346 & 8252 & 11710 & 13242 & 14860 & 11162 & 12844 & 14622 & 7040 & 8066 & 9254 & 6639 & 7334 & 8072 \\
\hline Montenegro & 2409 & 3152 & 4013 & 4316 & 5692 & 7229 & 3878 & 5323 & 6974 & 2198 & 2991 & 3993 & 2202 & 2769 & 3413 \\
\hline Morocco & 1088 & 1607 & 2255 & 1944 & 2906 & 4064 & 1735 & 2748 & 3998 & 901 & 1452 & 2231 & 959 & 1363 & 1865 \\
\hline Mozambique & 82 & 202 & 466 & 145 & 368 & 842 & 103 & 285 & 678 & 33 & 94 & 234 & 53 & 116 & 233 \\
\hline Myanmar & 229 & 377 & 626 & 409 & 683 & 1129 & 353 & 608 & 1011 & 177 & 294 & 483 & 202 & 302 & 441 \\
\hline Namibia & 603 & 914 & 1360 & 1077 & 1653 & 2453 & 1046 & 1652 & 2492 & 624 & 980 & 1500 & 569 & 833 & 1183 \\
\hline Nepal & 1374 & 1905 & 2578 & 2460 & 3442 & 4645 & 2230 & 3224 & 4464 & 1281 & 1807 & 2511 & 1250 & 1635 & 2095 \\
\hline Netherlands & 2351 & 3216 & 4191 & 4208 & 5809 & 7551 & 3767 & 5443 & 7328 & 2039 & 2937 & 4089 & 2058 & 2701 & 3434 \\
\hline New Zealand & 1130 & 1936 & 2896 & 2013 & 3504 & 5219 & 1640 & 3142 & 4973 & 628 & 1342 & 2385 & 784 & 1335 & 2017 \\
\hline Nicaragua & 0 & 6 & 123 & 0 & 10 & 223 & 0 & 2 & 65 & 0 & 0 & 1 & 0 & 0 & 5 \\
\hline Niger & 124 & 261 & 470 & 220 & 473 & 848 & 247 & 531 & 942 & 179 & 375 & 665 & 180 & 335 & 533 \\
\hline Nigeria & 52 & 119 & 251 & 91 & 217 & 452 & 91 & 221 & 423 & 58 & 134 & 252 & 64 & 127 & 210 \\
\hline Norway & 4890 & 5855 & 6871 & 8773 & 10561 & 12375 & 8077 & 10033 & 12023 & 4895 & 6064 & 7380 & 4773 & 5569 & 6390 \\
\hline Oman & 123 & 261 & 490 & 217 & 473 & 884 & 169 & 405 & 807 & 62 & 156 & 345 & 90 & 181 & 328 \\
\hline Pakistan & 900 & 1241 & 1676 & 1611 & 2242 & 3021 & 1465 & 2122 & 2943 & 827 & 1185 & 1679 & 826 & 1090 & 1415 \\
\hline Palestine & 263 & 626 & 1175 & 465 & 1137 & 2119 & 330 & 964 & 1933 & 84 & 333 & 815 & 147 & 364 & 693 \\
\hline Panama & 0 & 0 & 0 & 0 & 0 & 0 & 0 & 0 & 0 & 0 & 0 & 0 & 0 & 0 & 0 \\
\hline Papua New Guinea & 0 & 16 & 205 & 0 & 31 & 372 & 0 & 5 & 143 & 0 & 0 & 2 & 0 & 1 & 12 \\
\hline Paraguay & 222 & 413 & 749 & 396 & 749 & 1351 & 311 & 615 & 1143 & 128 & 245 & 451 & 158 & 262 & 421 \\
\hline Peru & 1250 & 1889 & 2680 & 2233 & 3416 & 4831 & 1874 & 3066 & 4524 & 904 & 1464 & 2268 & 966 & 1401 & 1934 \\
\hline Philippines & 0 & 0 & 0 & 0 & 0 & 0 & 0 & 0 & 0 & 0 & 0 & 0 & 0 & 0 & 0 \\
\hline Poland & 3362 & 4166 & 5080 & 6030 & 7518 & 9151 & 5500 & 7070 & 8821 & 3287 & 4161 & 5234 & 3258 & 3875 & 4558 \\
\hline Portugal & 787 & 1434 & 2293 & 1401 & 2598 & 4133 & 1079 & 2234 & 3795 & 395 & 880 & 1675 & 519 & 925 & 1466 \\
\hline Congo & 0 & 5 & 92 & 1 & 9 & 167 & 0 & 3 & 41 & 0 & 0 & 2 & 0 & 1 & 4 \\
\hline Romania & 3198 & 3967 & 4860 & 5736 & 7158 & 8755 & 5233 & 6714 & 8406 & 3131 & 3943 & 4948 & 3088 & 3667 & 4316 \\
\hline Russia & 4797 & 5606 & 6515 & 8611 & 10110 & 11733 & 8026 & 9623 & 11367 & 4952 & 5867 & 6952 & 4866 & 5505 & 6195 \\
\hline Rwanda & 33 & 350 & 1084 & 57 & 642 & 1957 & 11 & 299 & 1474 & 1 & 16 & 205 & 7 & 82 & 322 \\
\hline
\end{tabular}




\begin{tabular}{|c|c|c|c|c|c|c|c|c|c|c|c|c|c|c|c|}
\hline $\begin{array}{c}\text { HDD } \\
\text { Average 1964-2013 }\end{array}$ & $\begin{array}{l}\text { Temp } \\
15.6^{\circ} \mathrm{C}\end{array}$ & $\begin{array}{l}\text { Temp } \\
18.3^{\circ} \mathrm{C}\end{array}$ & $\begin{array}{l}\text { Temp } \\
21.1^{\circ} \mathrm{C}\end{array}$ & $\begin{array}{l}\text { Temp } \\
60^{\circ} \mathrm{F}\end{array}$ & $\begin{array}{l}\text { Temp } \\
65^{\circ} \mathrm{F}\end{array}$ & $\begin{array}{l}\text { Temp } \\
70^{\circ} \mathrm{F}\end{array}$ & $\begin{array}{c}\text { Heat } \\
\text { Index } \\
57.56^{\circ} \mathrm{F}\end{array}$ & $\begin{array}{c}\text { Heat } \\
\text { Index } \\
63.08^{\circ} \mathrm{F}\end{array}$ & $\begin{array}{c}\text { Heat } \\
\text { Index } \\
68.58^{\circ} \mathrm{F}\end{array}$ & $\begin{array}{l}\text { Humidex } \\
13.98^{\circ} \mathrm{C}\end{array}$ & $\begin{array}{l}\text { Humidex } \\
17.4^{\circ} \mathrm{C}\end{array}$ & $\begin{array}{l}\text { Humidex } \\
21.09^{\circ} \mathrm{C}\end{array}$ & $\begin{array}{c}\text { ESI } \\
12.6^{\circ} \mathrm{C}\end{array}$ & $\begin{array}{c}\text { ESI } \\
14.9^{\circ} \mathrm{C}\end{array}$ & $\begin{array}{c}\text { ESI } \\
17.2^{\circ} \mathrm{C}\end{array}$ \\
\hline Saudi Arabia & 357 & 583 & 911 & 638 & 1056 & 1642 & 615 & 1058 & 1692 & 360 & 618 & 1033 & 341 & 542 & 828 \\
\hline Senegal & 17 & 47 & 115 & 30 & 86 & 208 & 32 & 92 & 215 & 23 & 63 & 145 & 26 & 63 & 125 \\
\hline Serbia & 2934 & 3703 & 4586 & 5259 & 6683 & 8262 & 4765 & 6256 & 7944 & 2796 & 3612 & 4631 & 2782 & 3366 & 4020 \\
\hline Sierra Leone & 2 & 7 & 28 & 3 & 14 & 51 & 2 & 9 & 31 & 0 & 2 & 7 & 1 & 3 & 9 \\
\hline Slovakia & 3355 & 4148 & 5056 & 6017 & 7485 & 9107 & 5490 & 7030 & 8762 & 3290 & 4142 & 5189 & 3248 & 3851 & 4520 \\
\hline Slovenia & 3403 & 4245 & 5190 & 6101 & 7660 & 9349 & 5534 & 7172 & 8984 & 3278 & 4178 & 5280 & 3241 & 3878 & 4580 \\
\hline Somalia & 2 & 11 & 47 & 4 & 21 & 85 & 2 & 13 & 61 & 0 & 3 & 16 & 2 & 6 & 21 \\
\hline South Africa & 969 & 1458 & 2152 & 1733 & 2637 & 3879 & 1554 & 2430 & 3684 & 885 & 1311 & 1970 & 840 & 1171 & 1621 \\
\hline South Korea & 2094 & 2724 & 3477 & 3753 & 4919 & 6265 & 3411 & 4626 & 6026 & 1999 & 2668 & 3494 & 1884 & 2359 & 2891 \\
\hline South Sudan & 2 & 14 & 97 & 4 & 25 & 176 & 4 & 22 & 106 & 4 & 16 & 52 & 5 & 18 & 51 \\
\hline Spain & 1920 & 2627 & 3443 & 3436 & 4745 & 6204 & 3084 & 4464 & 6037 & 1679 & 2437 & 3406 & 1693 & 2234 & 2853 \\
\hline Sri-Lanka & 0 & 0 & 2 & 0 & 0 & 3 & 0 & 0 & 1 & 0 & 0 & 0 & 0 & 0 & 0 \\
\hline Sudan & 47 & 105 & 227 & 84 & 191 & 409 & 91 & 210 & 434 & 64 & 147 & 308 & 61 & 130 & 248 \\
\hline Swaziland & 305 & 600 & 1086 & 543 & 1088 & 1959 & 412 & 902 & 1697 & 147 & 337 & 682 & 207 & 380 & 638 \\
\hline Sweden & 3633 & 4517 & 5492 & 6514 & 8151 & 9893 & 5935 & 7682 & 9575 & 3539 & 4526 & 5720 & 3483 & 4173 & 4928 \\
\hline Switzerland & 4243 & 5148 & 6130 & 7612 & 9286 & 11042 & 6957 & 8758 & 10664 & 4202 & 5237 & 6451 & 4100 & 4815 & 5576 \\
\hline Syria & 1201 & 1685 & 2279 & 2149 & 3045 & 4108 & 1923 & 2858 & 3984 & 1039 & 1542 & 2218 & 1051 & 1418 & 1859 \\
\hline Tajikistan & 4454 & 5271 & 6161 & 7995 & 9506 & 11096 & 7497 & 9164 & 10918 & 4731 & 5762 & 6948 & 4374 & 5067 & 5799 \\
\hline Tanzania & 45 & 241 & 775 & 78 & 441 & 1399 & 39 & 260 & 1051 & 7 & 48 & 229 & 21 & 89 & 282 \\
\hline Thailand & 22 & 64 & 173 & 38 & 117 & 312 & 26 & 83 & 233 & 8 & 24 & 67 & 14 & 34 & 75 \\
\hline Togo & 13 & 41 & 108 & 23 & 76 & 195 & 18 & 64 & 157 & 8 & 28 & 69 & 14 & 36 & 71 \\
\hline Tunisia & 550 & 964 & 1527 & 979 & 1745 & 2753 & 835 & 1603 & 2648 & 382 & 750 & 1341 & 445 & 736 & 1129 \\
\hline Turkey & 2586 & 3280 & 4078 & 4636 & 5919 & 7347 & 4232 & 5600 & 7140 & 2482 & 3255 & 4219 & 2426 & 2973 & 3588 \\
\hline Turkmenistan & 2140 & 2689 & 3327 & 3837 & 4853 & 5994 & 3588 & 4698 & 5952 & 2201 & 2871 & 3710 & 2061 & 2531 & 3067 \\
\hline Uganda & 7 & 126 & 732 & 12 & 233 & 1324 & 2 & 74 & 791 & 0 & 2 & 43 & 1 & 16 & 109 \\
\hline Ukraine & 3298 & 4037 & 4893 & 5916 & 7284 & 8813 & 5439 & 6882 & 8512 & 3293 & 4104 & 5096 & 3220 & 3793 & 4430 \\
\hline $\begin{array}{l}\text { United Arab } \\
\text { Emirates }\end{array}$ & 154 & 308 & 559 & 274 & 559 & 1009 & 219 & 486 & 934 & 84 & 194 & 413 & 116 & 220 & 387 \\
\hline United Kingdom & 2256 & 3134 & 4108 & 4037 & 5662 & 7402 & 3584 & 5321 & 7216 & 1850 & 2806 & 4010 & 1922 & 2600 & 3356 \\
\hline United States & 2347 & 2942 & 3654 & 4209 & 5310 & 6583 & 3859 & 5010 & 6339 & 2310 & 2950 & 3741 & 2241 & 2695 & 3205 \\
\hline Uruguay & 681 & 1134 & 1771 & 1214 & 2053 & 3193 & 1008 & 1808 & 2929 & 449 & 807 & 1359 & 513 & 800 & 1183 \\
\hline Uzbekistan & 2649 & 3292 & 4021 & 4751 & 5940 & 7244 & 4442 & 5746 & 7182 & 2739 & 3532 & 4499 & 2566 & 3113 & 3720 \\
\hline Venezuela & 0 & 2 & 57 & 0 & 4 & 104 & 0 & 0 & 29 & 0 & 0 & 0 & 0 & 0 & 1 \\
\hline Vietnam & 111 & 227 & 444 & 198 & 412 & 801 & 150 & 329 & 659 & 58 & 122 & 243 & 75 & 134 & 229 \\
\hline Yemen & 70 & 185 & 415 & 124 & 336 & 749 & 94 & 275 & 671 & 39 & 100 & 263 & 52 & 121 & 260 \\
\hline Zambia & 207 & 452 & 946 & 367 & 821 & 1707 & 320 & 712 & 1506 & 142 & 326 & 661 & 170 & 326 & 585 \\
\hline Zimbabwe & 428 & 734 & 1232 & 764 & 1329 & 2221 & 676 & 1223 & 2068 & 325 & 600 & 1028 & 356 & 574 & 875 \\
\hline
\end{tabular}




\section{About the research team}

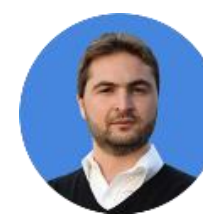

Tarek Atallah is a Senior Research Analyst evaluating energy productivity investments, economics of energy vulnerability, and the effect of climate on energy consumption patterns.

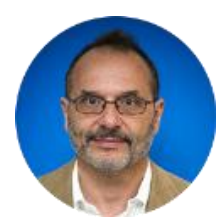

Alessandro Lanza is a Senior Visiting Fellow and an expert in the fields of energy and environmental markets, economics and climate change policy. He has written more than 50 papers and books on energy policy, climate change, sustainable development.

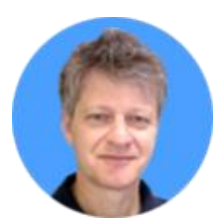

Silvio Gualdi is head of the Climate Simulations and Predictions Division at the EuroMediterranean Centre on Climate Change. His research focuses primarily on investigating the mechanisms of climate variability and climate change.

\section{About the project}

The CMCC-KAPSARC Database is a comprehensive open source database that includes heating and cooling degree days for 147 countries spanning 60 years. In addition to being a source for traditional temperature-based degree days, the team has presented a novel approach that incorporates the effect of humidity and solar radiation by deriving degree days from thermal comfort indices. Its intent is to provide a quantitative means for assessing climatic effects when performing energy-related analyses.

Please see the link below for the CMCC-KAPSARC Database:

http://www.kapsarc.org/en/Documents/KAPSARC-CMCC\%20Enhanced\%20Degree\%20Days\% 20\%20Database $\% 20$ March $\% 202015$.xlsx 